\title{
Meteorological and hydrological analysis of major floods in NE Iberian Peninsula
}

\author{
David Pino ${ }^{\text {a,b }}$, Josep Lluís Ruiz-Bellet ${ }^{\mathrm{c}}$, Josep Carles Balasch ${ }^{\mathrm{c}}$, Laura \\ Romero-León $^{\mathrm{d}}$, Jordi Tuset ${ }^{\mathrm{e}, \mathrm{f}}$, Mariano Barriendos ${ }^{\mathrm{g}}$, Jordi Mazon ${ }^{\mathrm{a}}$, Xavier \\ Castelltort $^{\mathrm{C}}$ \\ ${ }^{a}$ Department of Physics, Universitat Politècnica de Catalunya.BarcelonaTech, Castelldefels, \\ Spain \\ ${ }^{b}$ Institute of Space Studies of Catalonia (IEEC-UPC), Barcelona, Spain \\ ${ }^{c}$ Department of Environment and Soil Sciences, University of Lleida, Lleida, Spain \\ ${ }^{d}$ Escola d'Enginyeria de Telecomunicacions i Aeroespacial de Castelldefels, Universitat \\ Politècnica de Catalunya.BarcelonaTech, Castelldefels, Spain \\ ${ }^{e}$ Forest Sciences Centre of Catalonia, Solsona, Spain \\ ${ }^{f}$ RIUS Fluvial Dynamics Research Group, University of Lleida, Lleida, Spain \\ ${ }^{g}$ Department of Modern History, University of Barcelona, Barcelona, Spain
}

\begin{abstract}
This paper analyses the meteorological conditions and the specific peak flows of 24 catastrophic floods that affected NE Iberian Peninsula in the period 1842-2000. We classify these floods according to the affected area, peak flow magnitude, and damages. Additionally, the NOAA 6 Hourly 20th Century V2 Reanalysis Data Composites have been used to analyze the synoptic conditions during each flood and to evaluate several stability indices, such as the convective available potential energy (CAPE), or the lift index.

We found a good correlation between stability indices and the season when the flood occurred. For instance, if maximum CAPE is considered, larger values are found for summer floods, moderate for autumn, and low values during winter floods. We select 5 representative episodes occurred in different seasons and
\end{abstract}

\footnotetext{
* Corresponding author

Email address: david.pino@upc.edu (David Pino)
}

Preprint submitted to Journal of Hydrology ${ }^{A} T_{E} X$ Templates

January 25, 2016

(C) 2016. This manuscript version is made available under the Elsevier user license http://www.elsevier.com/open-access/userlicense/1.0/ 
areas to describe in detail the synoptic conditions and to show the temporal evolution of the stability indices. In one the summer floods analyzed in detail, the largest instability, according to all the convective indices, is found. On the contrary, the winter case shows very low values of the convective indices, and autumn cases lay in between. During the other analyzed summer flood instability was low but snow thaw played an important role in producing the flood.

Regarding hydrological variables, clear differences between floods occurred at the coast or at the Pyrenees are found. Coastal specific peak flows are larger than Pyrenean ones, especially for small catchment areas.

We also combine meteorological (rainfall duration, CAPE), hydrological (specific peak flow) and geomorphological (catchment area) variables to show that for many of the analyzed floods these variables are related: the specific peak flow generally shows larger values when CAPE is also large. However some differences appear depending on the season and area. In those summer floods, where snow thaw played doesn't played any role, either Pyrenean or coastal, specific peak flow seems to be correlated with CAPE. For autumn floods, depending on the area different correlations were found: Pyrenean floods seem to be a correlation between CAPE and specific peak flows, but not for coastal ones. For winter coastal floods we couldn't find any correlation between CAPE and specific peak flows.

Keywords: historical floods; flash floods; multidisciplinary reconstruction; specific peak flow; Twentieth Century Global 


\section{Reanalysis V2; stability indices}

\section{Introduction}

Flash floods caused on average 50 casualties per year in Europe, $70 \%$ of the total number of deaths due to floods (Barredo, 2007). The fatalities mainly occur in countries surrounding the Mediterranean Sea, where large population

5 density exists at the coastal areas due to the important urbanization processes in this area occurred during the last decades (Llasat et al., 2010). Particularly in Spain, almost $90 \%$ of the victims due to floods are caused by flash floods (Olcina \& Ayala-Carcedo, 2002). For instance, the Santa Tecla flash flood on September 1874 affected coastal and pre-coastal areas and caused the death of more than 500 persons (Ruiz-Bellet et al., 2015), or the floods on September 1962, when more than 850 persons died or disappeared (Tomás, 1963; Mazon \& Pino, 2012), or more recently, in August 199687 people died in Biescas (North of Spain, García-Ruiz et al. (1996)).

Hydrological flash floods are produced by extreme precipitation events due to convective processes, normally of short duration and affecting a limited area. Accumulated precipitation use to be larger than $100 \mathrm{~mm}$ in few hours (Llasat et al., 2008; Gaume et al., 2009), but some authors report episodes that lasted up to $34 \mathrm{~h}$ (Marchi et al., 2010). This extreme precipitation produced a hydrological response-time usually smaller than 6 h (Georgakakos \& Hudlow, 1984), but it 20 can be up to $16 \mathrm{~h}$ (Marchi et al., 2010).

There is a change in the response time when the catchment is larger that 
$350 \mathrm{~km}^{2}$ (Gaume et al., 2009), although the most destructive floods occur in catchments below this size (Marchi et al., 2010). Additionally, the severity criteria are also ambiguous and can involve rainfall or peak flow return period 25 (Norbiato et al., 2008) and indices that include economic losses.

Despite the fact floods produce huge social and economic impacts, due to its low frequency and the difficulty to obtain reliable measurements there are still many unknowns related to this natural hazard, with scarce reliable quantitative databases (Benito et al., 2005; Brázdil et al., 2006; Barriendos et al., 2014). so Additionally, regarding the difficulties to forecast flash floods (Gaume et al., 2009), it is fundamental to increase the knowledge about the spatio-temporal dynamics of flash floods to improve their forecast and the land-use planning. This fact will be important in the coming years because the severity and damages are expected to increase due to global change and the increasing urbanization 35 development Borga et al. (2011).

Previous works have analyzed the characteristics of the catastrophic flash floods generally using databases restricted to the second half of the last century (Gaume et al., 2009; Marchi et al., 2010). The 'Prediflood' database (Barriendos et al., 2014) has quantitative data and reconstructions of floods occurred in the 40 NE of the Iberian Peninsula over the last 500 years. By using this database, the most catastrophic flash floods since mid XIX century affecting more than one catchment in the area of interest are selected and studied. For each flood, we analyze the synoptic conditions by using the NOAA 20th Century Reanalysis. Additionally, we estimate some convective indices and relate their values with 
some hydrological variables, such as specific peak flow.

In Section 2, previous works analyzing the atmospheric conditions producing high rainfall rates in the NE Spanish coastal are described. Section 3 describes the studied area whereas Section 4 explains the methodology used to analyze the floods. The results are presented in Section 5, where a general description of the floods attending the meteorological and hydrological variables is done. Additionally, in this Section 5 representative floods are studied with more detail. The paper ends with some conclusions.

\section{Analysis of the atmospheric conditions producing torrential pre- cipitation in Northeast Iberian Peninsula} caused by the precipitation have been studied according to climate (Millán, 2014) or analyzing particular episodes. Most studies focus on one of these main areas: trends in precipitation, circulation types associated to precipitation in different areas in the Iberian Peninsula (IP), and the atmospheric conditions of recent important precipitation events. Moreover, most of the studies are limited to analyze the tendencies in the last 50-70 years when the density of automated weather stations was large enough (Ramis et al., 2013).

Regarding general trends of precipitation, Lana et al. (2004); GonzálezHidalgo et al. (2009); Barrera-Escoda \& Llasat (2015) studied the spatio-temporal trends of rainfall in the Mediterranean area of Spain. Additionally, several authors pointed out the lack of correlation between torrential precipitation records 
at the Mediterranean coast of the IP and the low variability modes: North Atlantic Oscillation, Mediterranean Oscillation, and Western Mediterranean Oscillation (Rodó et al., 1997; Martín-Vide \& López-Bustins, 2006; Martín-Vide 70 et al., 2008; Muñoz-Díaz \& Rodrigo, 2006; González-Hidalgo et al., 2009; Castro et al., 2011).

Other authors related circulation patterns and precipitation in the Mediterranean basin (Dünheloh \& Jacobeit (2003), see Dayan et al. (2015) for a review) or particularly in the IP (Romero et al., 1999b; Goodess \& Jones, 2002; Este75 ban et al., 2005; Casado et al., 2010; Fernández-Montes et al., 2014). Specifically, Romero et al. (1999a) classified the precipitation patterns in the Spanish Mediterranean area in the period 1964-1993 identifying 11 different patterns and 8 patterns of torrential precipitation (more than $50 \mathrm{~mm}$ in $24 \mathrm{~h}$ ). Romero et al. (1999b); Romero \& Ramis (2002) used this classification to associate the so patterns to circulation types obtained from the European Centre for MediumRange Weather Forecast (ECMWF) gridded data at 925 and $500 \mathrm{hPa}$. The torrential rainfall at the northeast of the IP were mainly associated to circulation types 8 and 18. Circulation type 8 appears in spring, autumn and summer and presents a surface frontal low over northeast IP. 18 is characterized by a surface low located over the gulf of Genoa. In both types a trough at $500 \mathrm{hPa}$ over the IP brings cold air to the upper levels. Due to the difficulties to obtain an accurate dataset of precipitation, most of these studies only present precipitation events or the tendency of precipitation since the middle of the last century. 
Regarding the study of particular episodes in the northeast area of the IP, previous studies analyzed the atmospheric conditions to produce large rainfall rates of some of the events included here, but without considering in many cases the consequences (floods) of these precipitation rates. Additionally, there are few studies analyzing the atmospheric conditions responsible for floods occurring before 1980 (Tomás, 1963, 1972; Alonso \& Puigserver, 1978). These studies, except Alonso \& Puigserver (1978), only analyzed surface pressure data to describe the synoptic conditions that cause the floods. Alonso \& Puigserver (1978) used radiosondes launched at four different locations in the northwestern Mediterranean coast to analyze the upper troposphere conditions during two floods on 1971. Consequently, there are few studies analyzing, by using a high-resolution mesoscale models including data in the upper levels of the troposphere, the atmospheric conditions during a catastrophic flash flood occurred before 1980 in the area under study. Llasat et al. (2007); Mazon \& Pino (2012) tried, with limited success, to reproduce the precipitation occurred during the floods in September 1971 and September 1962, respectively. Two main reasons explain this lack studies analyzing floods that occurred before 1950 in this area:

- First, as it was mentioned before, there only exist reliable and enough density of precipitation measurements in the area since 1950 (Ramis et al., 2013). Consequently, if recorded rainfall, and not the flood itself, is used as starting point for any research, the studies are limited to instrumentation periods. By using the 'Prediflood' database (Barriendos et al., 2014), which largely increase the number of episodes of previous databases 
(Barnolas \& Llasat, 2007), we are able to analyze episodes occurred before this period.

- Second, until recently only monthly surface pressure data were available between 1780 and 1950. However, by using the Twentieth Century Global Reanalysis V2 (Compo et al., 2011) additional variables (temperature, humidity, winds, ...) at different vertical levels are available since 1871 .

Ramis et al. (1994) studied the October-1987 floods affecting Catalonia (431 $\mathrm{mm}$ in 7 days, 24-h accumulated precipitation 175 and $177 \mathrm{~mm}$ at El Prat and Girona airports, respectively on 3 October) by using rain gauge data and numerical modeling. The main synoptic factors that produced the extreme precipitation were convective instability (convective available potential energy (CAPE) larger than $3000 \mathrm{~J} \mathrm{~kg}^{-1}$ ) and moisture convergence at low levels. They also showed that a line of convergence appeared near the coast separating warm and humid air over the Mediterranean sea and a cold outflow.

Codina et al. (1997) and Ramis et al. (1998) studied, by using the MASS mesoscale model and ECMWF data, respectively, the atmospheric conditions that produced the torrential precipitation (240 $\mathrm{mm}$ in 2.5 hours) occurred in Catalonia on 9 and 10 October 1994. The episode was characterized by a high pressure area over Europe and a low pressure center over the Algerian coast. At upper levels a trough affected the southwest of Spain. Despite the numerical model underestimates the observed precipitation in both cases, Ramis et al. (1998) used it to study the role of orography and evaporation in the precipi135 tation. They found that the orography played a major role in producing the 
rainfall rates and evaporation was less important.

Llasat et al. (2003) used observations and synoptic data from the Meteorological Office of Catalonia (METEOCAT) to describe the atmospheric conditions during the flood on June 2000 in Catalonia (1-h accumulated precipitation ${ }_{140}$ larger than $100 \mathrm{~mm}$ ). They found CAPE higher than $1000 \mathrm{~J} \mathrm{~kg}^{-1}$, and large values of Lifted Index (LI) and Precipitable Water (PW), and a convergence line over the area affected by the rain clearly observed at the surface wind records. Additionally they compared the synoptic conditions and some instability index of the 2000 flood with some historical catastrophic floods affecting the Llobre145 gat valley. For instance, they estimated rainfall, CAPE and LI index for the 2000 and 1962 episodes obtaining comparable values. Regarding the climatic variability of this type of events they were not able to reach any conclusion probably due to the limited size of the dataset.

More recently Trapero et al. (2013b) used the Weather Research and Forecast 150 model (WRF, Skamarock et al. (2008)) to study influence of the orography on the atmospheric conditions during two heavy precipitation episodes $(24-\mathrm{h}$ accumulated precipitation larger than $100 \mathrm{~mm}$ ) affecting the Eastern Pyrenees on November 2008 and October 2010. In general, the domain of the model (3 $\mathrm{km})$ with the higher resolution is able to reproduce the observed precipitation but the domains with coarser resolution clearly underestimate the observed rainfall rates. They conclude that is very important to identify the source of the moisture flows and its evolution and the interaction with the orography. In a companion paper Trapero et al. (2013a) used MesoNH mesoscale model (Lafore 
et al., 1998) to study the heavy precipitation event affecting the same area on November 1982. By analyzing the mesoscale model results, they identify four phases in the episode and the mechanisms necessary for precipitation, being the orography the dominant triggering mechanism of convection (Lin et al., 2001).

By using a multidisciplinary approach, here we analyze the most catastrophic floods affecting the NE area of the IP (see Section 3) according to the methodology described in Section 4.1. Particular emphasis has been put in the separation of the different catchments of the area under study and in the meteorological conditions, specially regarding the stability of the atmosphere, that produced the flood. To analyze the synoptic conditions and calculate the stability indices of the episodes, and despite the low horizontal resolution, the NOAA Twentieth Century Global Reanalysis V2 is used (see Section 4.2).

\section{Description of the studied area}

The study area is located in NE Iberian Peninsula. The climate within the study area is Mediterranean (Köppen Csa), usually with mild winters and hot, dry summers. The area covers a surface of $27189 \mathrm{~km}^{2}$ and it can be divided in three major hydroclimatic units (see Fig. 1):

- The Pyrenees: a mountain range in the north with a $\mathrm{E}-\mathrm{W}$ orientation, with maximum heights over $3000 \mathrm{~m}$., and most of the area above 1000 m. It is the greatest orographic barrier in the study area, with bedrock of Paleozoic, Mesozoic and Cenozoic rocks and forests and meadows on welldrained mountain soils. The climate in this unit is more humid (700-1300 
mm $\mathrm{yr}^{-1}$ ), so much so that the Upper Garona catchment can be classified as having an Oceanic climate (Köppen Cfb). Besides, the highest areas have an Alpine climate (Köppen ET).

- The Catalan Mediterranean System: a mountain range that runs parallel to the coast with heights lower than $1500 \mathrm{~m}$. It is a barrier to air masses coming from the Mediterranean. It has sandy soils on granites and silts of Paleozoic and Mesozoic rocks. Seven million people (95\% of the total population within the study area) live at the foot of this range. The climate is typical Mediterranean and mean annual rainfall lies between 500 and $800 \mathrm{~mm} \mathrm{yr}^{-1}$.

- Ebro Basin: this area includes the easternmost part of the Ebro Basin, with heights between 80 and $700 \mathrm{~m}$, and an extensive agricultural use (both dry-land and irrigated) on carbonated detrital soils. The Mediterranean climate in this unit is more continental and, thus, much dryer (350-500

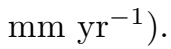

Besides this spatial heterogeneity in mean annual rainfall within the study area, there is also a temporal heterogeneity throughout the year, with a high probability of torrential rains in any season but especially in summer and autumn, caused by diverse mechanisms: Atlantic fronts, convective summer rainstorms, and Mediterranean cyclogenesis (Millán, 2014).

The study area can be divided in eleven hydrologically homogeneous subareas or groups of catchments, hereafter called hydrological units (Fig. 1), the 
main characteristics of which are gathered in Table 1.

Hydrologically, these units can be classified according to their headwaters location. On the one hand, there are the small and medium coastal catchments, with headwaters in the Catalan Mediterranean System that flow directly into the Mediterranean. Mean annual rainfall in these hydrological units is $695 \mathrm{~mm}$ $\mathrm{yr}^{-1}$. Runoff generation mechanisms within this kind of catchments are, predominantly, infiltration excess overland flow (or Hortonian flow) and saturation excess overland flow (Gallart \& Berliner, 2011) and the mean runoff coefficient is $23.2 \%(\mathrm{ACA}, 2002)$.

The rivers are purely rain-fed, with generally low flows (always under 10 $\mathrm{m}^{3} \mathrm{~s}^{-1}$ ), which reach their maximum in autumn and their lowest in summer. Moreover, some torrents (locally called "rieres") are intermittent: they dry up in summer or after droughts, and some others are even ephemeral: they only flow after rain events. Both types of torrent, but especially the latter, which usually have small catchments and high longitudinal slopes and, thus, very short lag times, are prone to very dangerous flash floods.

According to Barnolas \& Llasat (2007), floods in these hydrological units 220 occur generally in autumn. Floods have augmented since the 1960s because of the increased imperviousness of the catchments due to intense urbanization and greenhouse agriculture (up to $40 \%$ of the catchment area in the most extreme cases), the infrastructure construction within the watercourses and forest fires (Sala \& Inbar, 1992; Conacher \& Sala, 1998; Hooke, 2006). 
On the other hand, there are the catchments with their headwaters in the Pyrenees, which flow into either the Mediterranean or the Ebro River. These catchments are generally larger than the coastal ones (up to $12450 \mathrm{~km}^{2}$ ) and occupy $77 \%$ of the study area $\left(21054 \mathrm{~km}^{2}\right)$. Having their headwaters in the Pyrenees, these catchments receive more abundant precipitation than their coastal counterparts. The catchments are on steep but deep, well-developed mountain soils, and the main runoff generation mechanisms are saturation excess overland flow and subsurface return flow (Gallart \& Berliner, 2011). The runoff coefficient of the Segre unit is $26.8 \%$ (ACA, 2002).

The rivers in these hydrological units are rain- and snow-fed (up to $15 \%$ of the annual precipitation is in the form of snow). Rainfall occurs mainly in spring and autumn; however, late spring snow thaw has an important role in high flows. In late summer, flows decrease dramatically, but these rivers never dry up. Mean flows are between 20 and $100 \mathrm{~m}^{3} \mathrm{~s}^{-1}$.

The heaviest floods take place in early autumn in the eastern Pyrenees and 240 in late autumn in the western Pyrenees (Novoa, 1987). Natural forestation of the area related to rural population loss since the beginning of the twentieth century may have caused a reduction in river flows (Gallart \& Llorens, 2004; Cuadrat et al., 2007). However, there is no consensus on the effects of this process on the floods magnitude and frequency (Calder, 2007). 


\subsection{Selection of the analyzed floods}

The floods to be analyzed were selected from the 'Prediflood' database with a selection procedure. The 'Prediflood' is a database of historical floods occurred in Catalonia (NE Iberian Peninsula) between the 11th and the 21st century. It contains more than 2700 flooding records (i.e. locations with a flooding) corresponding to more than 1100 floods acquired under modern historiographical criteria and it is, therefore, suitable for meteorological and hydrological analyses (Barriendos et al., 2014). Flooding records within the 'Prediflood' database are classified according to the damages they caused in three categories: ordinary, extraordinary and catastrophic floods (Barriendos \& Pomés, 1993; Barriendos \& Martín-Vide, 1998; Llasat et al., 2005).

This classification was the basis of the flood selection procedure that works as follows: for each hydrological unit up to number 10, and in the order given in Fig. 1 and Table 1, the two floods with more flooding records classified as catastrophic were selected. If in one hydrological unit, one of the floods coincided with floods already selected in previously considered hydrological units, the next flood with more catastrophic flooding records was chosen. For example, the Northern coast unit, the two flooding events with a greater number of catastrophic cases are October 1987 and January 1977 with three and two, 265 respectively. However, observing that this selection procedure failed to pick some of the most notorious and extreme local floods, four floods were subsequently added to the list generated with the selection procedure: 1842, 1894, 
1963 and 1996 floods. Thus, a total of twenty-four floods were selected (Table 2). These floods were analyzed meteorologically and hydrologically. Additionally, five floods among these 24 were subsequently selected, due to their representativeness of summer, autumn and winter events, for a thorough meteorological analysis.

\subsection{Synoptic analysis and stability indices}

National Oceanic and Atmospheric Administration (NOAA) Earth System sity of Colorado CIRES Climate Diagnostics Center reanalysis products are available since 1 January 1871, having with 6 hours temporal resolution. The horizontal resolution is $2^{\circ} \times 2^{\circ}$ (Whitaker et al., 2004; Compo et al., 2006, 2011). The dataset includes surface or vertically integrated variables and vertical profiles. Depending on the variable between 20 and 30 vertical levels are available. To study the atmospheric conditions during the selected floods, temperature, specific humidity, geopotential height, and horizontal winds are studied at all the available pressure levels. Regarding $2 \mathrm{D}$ variables, surface pressure, CAPE (Mapes, 1993; Doswell III \& Rasmussen, 1994), convective inhibition (CIN),

285 and precipitable water are also analyzed. Besides studying the horizontal distribution of these variables during the episodes, additional stability indices are calculated at $42^{\circ} \mathrm{N}-0^{\circ} \mathrm{E}\left(42^{\circ} \mathrm{N}-2^{\circ} \mathrm{W}\right.$ for the flood occurred on August 1996). The stability indices presented for each flood are (Tudurí \& Ramis, 1997; Doswell III, 2001): 
a) $\mathrm{CAPE}=\int_{z_{L F C}}^{z_{e q}} g\left(\theta_{p}-\theta_{e n v}\right) / \theta_{e n v} d z$, where $\theta_{p}$, and $\theta_{e n v}$ are the potential temperature of the parcel and of the environment, respectively, and $z_{e q}$ is the height of the neutral buoyancy (Weisman \& Klemp, 1986). Depending on CAPE values (units $\mathrm{J}(\mathrm{kg})^{-1}$ ) the atmosphere can be classified as: marginally unstable $(0,1000)$, moderately unstable $(1000,2500)$, very unstable $(2500,3500)$, or extremely unstable $(>3500)$.

b) the Lifted Index: $\mathrm{LI}=\theta_{e 500}-T_{e 500}$, (Galway, 1956). If LI $>0$ the atmosphere is stable. Then, the instability is classified attending LI (units K) as: marginally unstable $(-4,0)$, largely unstable $(-7,-4)$, extremely unstable $(<-8)$.

e) Total Totals index: $\mathrm{TT}=T_{850}+T_{d 500}-2 T_{500}$, (Miller, 1972). TT (units K) classifies the atmospheric conditions as: convection not likely $(<44)$, thunderstorm likely $(44,50)$, isolated severe storms $(51,52)$, widely scattered severe storms $(53,56)$, and scattered severe storms $(>56)$.

Although some of the selected episodes occurred recently and, consequently, can be studied by using high resolution reanalysis data or mesoscale numerical simulations, to be consistent we only use the Twentieth Century Global Reanalysis V2 data to calculate these indices. It is important to note that CAPE obtained from a model is influenced by parameterizations (Molini et al., 2011). Ideally CAPE has to be calculated from radiosonde data but for many of the events presented here there was no radiosonde or it was launched hundreds of kilometers away from the location of the flood. 


\subsection{Relationships between meteorological and hydrological variables}

Twenty-four floods were analyzed in order to find relationships between meteorological an hydrological variables; of these floods, twenty were those selected

with the selection procedure explained in section 4.1 and the other four were added due to their relevance: 1842, 1894, 1963 and 1996.

The following variables were used to characterize each flood:

- Season of occurrence, with the following classification: spring (March, April, May), summer (June, July, August), autumn (September, October, November), and winter (December, January, February).

- Area where it rained mainly, with the following classification: Catalan Mediterranean System (hereafter abridged as 'coast') and Pyrenees (see Fig. 1).

- Approximate rainfall duration.

- Synoptic pattern, according to a three-typed classification: flash triggering effect, cutoff low and trough (see Section 4.2), and according to the atmospheric patterns producing significant rainfall rates in the Mediterranean Spanish coast proposed by Romero et al. (1999b).

- Maximum daily convective available potential energy (CAPE) within the period of the flood (see Section 4.2).

- Maximum specific peak flow, which is the largest value of the ratio 'peak flow/catchment area' among all the catchments smaller than $2000 \mathrm{~km}^{2}$ with either a measured, calculated or reconstructed peak flow. 
Not all the 24 floods had data of all the studied variables: 4 of the 24 floods lacked peak flow values (1894, 1897, 1898 and 1901) and, therefore, the analysis of these floods was less complete. Besides, being 1871 the oldest date with Twentieth Century Global Reanalysis V2 data available, the meteorological variables (that is, the synoptic pattern, and stability indices) could not be determined for the 1842 flood. The sources of these variables were diverse: are listed in Table 3. A total of 225 peak flow values were gathered in 108 catchments smaller than $2000 \mathrm{~km}^{2}$ within the studied area for the 20 selected floods with such data available.

- Synoptic pattern was analyzed and stability indices were calculated by using data from the Twentieth Century Global Reanalysis V2, as explained in Section 4.2 .

Additionally, we have selected five episodes to describe in detail the synoptic conditions and the evolution of the stability indices during the flood. Autumn 1937 and 1951 floods have been chosen as representative episodes for this season. The first one affected the Pyrenees basins and the second one the coastal area. Taking into account that all the winter episodes only affected the coast, January 1977 is selected as representative for a winter flood. Two episodes occurring in summer are selected: 1963 as representative of a summer thunderstorm and 1897 as a characteristic episode where snow melt also played a major role. 


\section{Results}

The main characteristics of each flood, represented by using the variables defined in Sect. 4.3, are shown in Table 4.

\subsection{Combined meteorological and hydrological analysis of the 24 selected floods}

Among all the analyzed catastrophic floods, none occurred in spring, 7 octrough $(7,29 \%)$, high-altitude low (5, 21\%) flash triggering (1, 4\%, Mazon et al. (2014)) and $2(\% 8)$ not classified events $(1842,1994)$. Cutoff low seems to be the main mechanism producing the rain in summer, whereas trough is most typical in autumn, and no prevalent flood-causing pattern can be identified in 375 winter. Cutoff and trough seem to be equally prevalent in both studied areas (coast and Pyrenees), whereas no high-altitude lows have been observed among 
the rain events that affected the Pyrenees (Table 4).

If a more detailed description of the atmospheric patterns (APs) is used (Romero et al., 1999b), the synoptic conditions during the analyzed floods agree 380 with 11 of the 19 APs described by these authors (see their Fig. 5). In some cases, the longest episodes, more than one AP occurred during the flood (see Table 4). The most common AP related to the presented floods is AP4 (it was responsible of 6 of the studied floods: 1874, 1894, 1897, 1901, 1907, 1987) then AP3 (4), AP6 (3), AP1 (2) and AP14 (2). Different APs occurred during the other floods. AP4 is the most frequent of the patterns analyzed by (Romero et al., 1999b), "represents southwesterly flows at all levels associated with low pressure to the northwest of Spain" and it mainly occurs during autumn.

Regarding the duration of the rain event that caused each flood, summer events and autumn events in the coast have a wide range of durations (from scarcely $1.5 \mathrm{~h}$ up to 4 days) whereas winter events and autumn events in the Pyrenees all last more than 24 hours.

The stability indices during the studied summer floods, except in 1875, and to a lesser extent in 1897, floods, indicate large convective instability (mean CAPE $\sim 1350 \mathrm{~J} \mathrm{~kg}^{-1}$ ) of the atmosphere in the Western Mediterranean area 395 (Tudurí \& Ramis, 1997). During the 1875, and 1897 floods, that occurred at the beginning of the summer, snow melt was also a decisive factor to cause the flood. On the contrary, during the studied winter floods the atmosphere was characterized by very low values of the stability indices (mean CAPE $\sim 280 \mathrm{~J}$ $\mathrm{kg}^{-1}$, and positive values of LI). 
The atmosphere during autumn floods shows a wide range of stability indices, specially those episodes occurring at the coastal areas, being the mean CAPE $850 \mathrm{~J} \mathrm{~kg}^{-1}$. During autumn the combination of low temperatures in the upper troposphere with large surface temperatures and the large amount of moisture supplied by the Mediterranean Sea produces the majority of the catastrophic floods in the area under study.

Figure 2 shows, for each episode, the maximum CAPE at $42^{\circ} \mathrm{N}-2^{\circ} \mathrm{E}$ as a function of the duration of the precipitation (for references see Table 3). Each episode is marked depending on the season when it occurred and the location of the affected basins (coast, Pyrenees). It can be observed that the values of CAPE for the analyzed floods are not extreme according to the standard classification. Moreover, it is important to remind that CAPE is only the available potential energy and a large value of CAPE is not a sufficient condition to produce large rainfall rates. No clear differences in CAPE or duration exist depending on the affected area. However, some differences can be noticed 415 depending on the different seasons. Regarding the summer floods, there is an inverse dependence between CAPE and duration of the episode. This dependence cannot be observed for the autumn episodes. For the winter episodes, taking into account the low values of CAPE, it is difficult to reach any conclusion.

Figure 3a plots the 225 specific peak flow values associated to 20 out of the 24 floods with such data collected from 108 catchments and subcatchments smaller than $2000 \mathrm{~km}^{2}$. Figure $3 \mathrm{~b}$ compares them with the highest specific flows ever measured or modeled in other catchments in the western Mediterranean 
basin. It can be observed that the specific peak flow decreases with the increase of the catchment area. Thus, discharges above $15 \mathrm{~m}^{3} \mathrm{~s}^{-1} \mathrm{~km}^{-2}$ only occur in 425 catchments smaller than $30 \mathrm{~km}^{2}$, whereas the largest catchment with a value above $9 \mathrm{~m}^{3} \mathrm{~s}^{-1} \mathrm{~km}^{-2}$ is $344 \mathrm{~km}^{2}$. Above this size, the largest specific peak flows are less than $2.5 \mathrm{~m}^{3} \mathrm{~s}^{-1} \mathrm{~km}^{-2}$. These values are comparable in magnitude to the highest specific flows ever measured or modeled in other catchments of the same range of sizes in the Mediterranean areas of Spain and France (see Fig. 3b). Indeed, the specific peak flow for the 2000 flood clearly surpasses the enveloping curve found by Montalbán et al. (1994) for floods in Catalonia and even the curve found by Marchi et al. (2010) for Mediterranean floods. Similarly, in all the range of catchment sizes, the heaviest specific peak flows are all well above the expected ones given by Montalbán et al. (1994) and ACA (2007) for a return period of 500 years.

All floods occurring in the Pyrenean region show specific discharges lower than $7 \mathrm{~m}^{3} \mathrm{~s}^{-1} \mathrm{~km}^{-2}$ with the exception of the flood occurred in 1996 in Biescas, which was extremely violent, short-lived and local, whereas in the coastal region at least 11 flooding records present specific peak flows above that value. 440 Similarly, if an approximate enveloping line joining the largest values in the Pyrenees is drawn, at least 17 coastal values fall above it (see Fig. 3a). This difference in specific peak flows between the two geographic areas could be explained by differences in the meteorological and hydrological (both natural and man-caused) processes. Extreme rainstorms with high intensities are caused 445 mainly by meteorological processes, which include large supplies of humid air 
coming from the Mediterranean Sea (E-SE direction). The pre-coastal mountain enhances the vertical movements of this air mass helping it to reach the level of free convection (LFC) (Llasat, 1990). Consequently, the coastal area is much more affected by this kind of event than the Pyrenees. There torrential rainfall rates usually occur when a southerly flow at low levels exists (MartínVide, 1985; Casas, 2005; Millán, 2014), but this airmass has a lower water vapor content than in the coast. Differences in the hydrological processes in both areas also explain Fig. 3a: smaller infiltration rates and water retention capacities in the coastal catchments due to shallower soils and more impervious surfaces, 455 caused, in turn, by urbanization, greenhouse agriculture and forest fires (Dunne \& Leopold, 1978; Sala \& Inbar, 1992; Rozalis et al., 2010). Therefore, infiltration excess overland flow, associated with short lag times and high specific peak flows (Hewlett \& Hibbert, 1967; Dunne \& Black, 1970), is more likely to occur in coastal catchments than in Pyrenean ones, as said in Sect. 4 and by ${ }_{460}$ Gallart \& Berliner (2011). However, catchment size and slope do not explain this difference because they are similar in both regions.

Figure 4 shows the maximum values of the specific peak flow for each of the 20 floods with such a datum against rainfall duration. The specific peak flow is smaller when the duration of the rain event increases. Besides, summer floods (except 1875, caused by a sudden snow thaw) are caused by short-lived rain events and some have high specific peak flows (above $15 \mathrm{~m}^{3} \mathrm{~s}^{-1} \mathrm{~km}^{-2}$ ). In contrast, both autumn events in the Pyrenees and winter ones in the coast are caused by rains of 24 or more hours and their specific peak flow values are 
smaller than 7 and $4 \mathrm{~m}^{3} \mathrm{~s}^{-1} \mathrm{~km}^{-2}$, respectively. Between these two extremes, lies the group of autumn events in the coast, with a wide range of rain event durations and three specific peak flow values above $9 \mathrm{~m}^{3} \mathrm{~s}^{-1} \mathrm{~km}^{-2}$.

Using rainfall duration as an indicator of rainfall intensity and assuming that soils are generally dryer in summer than in autumn, it seems that large specific peak flows are more frequently caused by extremely intense rains than by saturated soils, that is, that the main runoff production mechanism is infiltration excess more than saturation excess (Gallart \& Berliner, 2011). Conversely, for longer rain events, the main runoff production mechanism must be soil saturation excess, because rainfall intensity is low. The largest specific peak flow are caused by summer and autumn events, and the smallest ones by winter events; this agrees with current knowledge (Martín-Vide, 1985; Casas, 2005).

Figure 5 shows the maximum specific peak flow for each flood as a function of the maximum CAPE. It can be observed that: summer events (excluding the unique 1875) have very high CAPE values (above $1300 \mathrm{~J} \mathrm{~kg}^{-1}$ ) and, in two of the three instances, very high specific peak flows $\left(\geq 15 \mathrm{~m}^{3} \mathrm{~s}^{-1} \mathrm{~km}^{-2}\right)$, whereas 485 autumn Pyrenean events and winter coastal ones have lower CAPE values (less than 800 and $400 \mathrm{~J} \mathrm{~kg}^{-1}$, respectively) and moderate to low specific peak flows, and, again, autumn coastal events hold an intermediate position between these two extremes, with CAPE values up to $1430 \mathrm{~J} \mathrm{~kg}^{-1}$ and specific peak flows up to $18 \mathrm{~m}^{3} \mathrm{~s}^{-1} \mathrm{~km}^{-2}$.

From Fig. 5, we can state that:

- When all 20 floods are considered, there seems to be a moderate correlation 
between CAPE and the maximum specific peak flow, with the highest specific peak flows more abundant in the high CAPE region and the lowest specific peak flows more abundant in the low CAPE region.

- When only the summer floods, either Pyrenean or coastal, are considered, the maximum specific peak flow seems to have no correlation with CAPE. The former were floods caused by very local, very violent cloudbursts, whereas the latter was caused by a front that accelerated snow melt.

- Autumn Pyrenean floods: there seems to be a correlation between CAPE and specific peak flows. However, the values are limited to a very narrow range and, thus, any statement about this correlation remains venturous.

- Autumn coastal floods: there seems to be no correlation between CAPE and specific peak flows.

- Winter coastal floods: there seems to be no correlation between CAPE and specific peak flows.

\subsection{Synoptical and stability conditions of 5 representative floods}

\subsubsection{July 1897}

From 20 June until 3 July 1897 large rainfall rates are recorded at several places at the central Pyrenees region (Saint-Gaudens 216 mm, Luchon $160 \mathrm{~mm}$ ) but most of the precipitation felt between 2 and 3 July 1897 (123 mm at SaintGaudens and $160 \mathrm{~mm}$ at Luchon). According to Trutat (1898), during the first days of the episode, the summits were still covered by snow but when the 
clouds dissipated at the end of the episode there was no snow over the mountain summits.

The synoptic configuration of the atmosphere during this episode is characterized by a cutoff low formed on 29 June 1897 South of the British Islands (not shown). This cutoff low moved South affecting the IP and a cold airmass remained stationary at the upper levels during several days. Figure 6 shows the geopotential height (black contour lines), temperature (color contours) and wind field (arrows) on 1 July 1987 at 18 UTC (left) and 2 July at 12 UTC (right) at 500, 850, and $1000 \mathrm{hPa}$. It can be observed that the cutoff low at $500 \mathrm{hPa}$ with a temperature around $-16^{\circ} \mathrm{C}$ is located over the IP. This cutoff low was approximately stationary from 1 July until 3 July 1897 at 18 UTC when it dissipated. At 850 and $1000 \mathrm{hPa}$ the air masses did not have very high temperatures and consequently, the instability of the atmosphere was not very important. However, what mostly enhanced vertical movements over the Pyrenees, besides the orography, was the convergence between a cold airmass moving from the northwest with a warmer airmass coming from the South/Southeast. The calculated CAPE has moderate values in the area affected by the flood (see Section 5.2.6). For this case the flood probably occurred due to a combination of moderate rainfall rates and snow melting producing a large increase of the peak flow of the small basins in the central Pyrenees.

\subsubsection{August 1963}

During the night of 3 August 1963 intense precipitation produced floods ${ }_{535}$ in 7 basins located in Northern part of the studied region, at the Pyrenees. 
A peak flow of $436 \mathrm{~m}^{3} \mathrm{~s}^{-1}$ was estimated in the Garona river at Les Bordes, and the following in the Noguera Ribagorçana river: $460 \mathrm{~m}^{3} \mathrm{~s}^{-1}$ at Ginaster, $1000 \mathrm{~m}^{3} \mathrm{~s}^{-1}$ at Pont de Suert and $950 \mathrm{~m}^{3} \mathrm{~s}^{-1}$ at Escales (López-Bustos, 1981; Martín-Vide, 2002).

hPa every 12 hours from 2 August 1963 at 00 UTC until 4 August 1963 at 12 UTC. Figures 8 and 9 shows the same variables at 850 and $1000 \mathrm{hPa}$, respectively. At $500 \mathrm{hPa}$ a deep trough was located at the North Atlantic and reached the northwestern part of the IP on 2 August at 00 UTC. Afterwards, an airmass

545 with temperatures around $-18^{\circ} \mathrm{C}$ detached from the main flow and affected the northern part of the peninsula moving eastwards and finally north on 4 August 1963. At $850 \mathrm{hPa}$, a low located at the northwestern part of the peninsula produced a warm (around $20^{\circ} \mathrm{C}$ ) southerly flow to the Pyrenees area during the whole episode. At $1000 \mathrm{hPa}$ (see Fig. 9) a relative low located over North Africa produced light wind from the east or southeast bringing air with temperatures above $25^{\circ} \mathrm{C}$ to the region affected by the flood. Unlike the previous episode, the surface temperature were higher in August 1963 producing large instability in the area.

\subsubsection{5-28 October 1937}

The flood that occurred between 25-28 October 1937 affected 5 basins located at the Pyrenees mountain range. Some weather stations in the area recorded more than $200 \mathrm{~mm}$ between 21 and 30 October 1937 (Fontseré \& Galceran, 1938). 
The synoptic situation during this episode at 500, 850 and $1000 \mathrm{hPa}$ every

shown in Figs. 10, 11, and 12, respectively. At $500 \mathrm{hPa}$ a cutoff low moved South from the North Atlantic area to the IP bringing a low-temperature air over the IP. On 28 October 1937 the cutoff low vanished. At $850 \mathrm{hPa}$ (see Fig. 11), on 26 October at 00 UTC a relative low is located in front of the western coast of the IP producing a southern flow over the area under study. This wind brought southern warm air to the region under study and consequently moderate instability until 28 October 1937 . During the following days the low moved further East and North, and consequently Northerly winds started to affect the area decreasing the instability. At $1000 \mathrm{hPa}$, the relative low pressure area can be observed near the Atlantic coast of the IP on 26 October 1937 at 00 UTC and remained almost stationary during the next three days. As a consequence, warm air (temperature around $20^{\circ} \mathrm{C}$ ) coming from North Africa is advected over the area until 28 October 1937 when a new relative low appeared North of the IP.

\subsubsection{1-12 October 1951}

During this episode rain and floods affected 12 basins located near the central and north coasts of the region. During the first part of the flood (1-5 October 1951) rain affected basins located mainly at the central coast. Moderate rainfall rates were recorded (below $80 \mathrm{~mm}$ ) at many stations, but for some stations more ${ }_{580}$ than $100 \mathrm{~mm}$ were recorded in $24 \mathrm{~h}$. For instance, at Barcelona airport 106, 114, and $149 \mathrm{~mm}$ were recorded on 1, 2 and 3 October 1951, and at Teià $102 \mathrm{~mm}$ on 3 
October 1951 (Agencia Española de Meteorología, AEMET). During the second part of the flood $173 \mathrm{~mm}$ were recorded in $24 \mathrm{~h}$ at Argentona on 9 October or $115 \mathrm{~mm}$ at Calella on 12 October 1951. As was expected, the synoptic analysis 585 shows two different atmospheric conditions that produced these rainfall rates. Here we will focus on the synoptic conditions during the first part of the flood, occurring on 1-5 October 1951.

The synoptic features at $500 \mathrm{hPa}$ during the first days of the flood were similar to the 1937 flood. During this episode the synoptic analysis shows at $500 \mathrm{hPa}$ a cutoff low that separated from a trough in the North Atlantic area on 1 October 1951 at 06 UTC. This low with temperatures around $-18^{\circ} \mathrm{C}$ (higher compared with the 1937-episode) affected the IP during the next four days (see Fig. 13). Figures 14, and 15 shows the geopotential height, temperature and wind field at at 850 and $1000 \mathrm{hPa}$, respectively every 12 hours from 1 October 1951 at 00 UTC until 3 October 1951 at 12 UTC. At 850 and $1000 \mathrm{hPa}$ a relative low existed over the IP moving from the northwest to the southeast. This low produced a prevailing southeastern/eastern flow that brought warm air to the region and, as a consequence, increased the instability. By comparing Figs. 14, and 15 with Figs. 11, and 12, it can be qualitatively explained why the rain and flood affected different areas on 1937 and 1951. During the 1937 floods the prevailing winds at the low levels of the troposphere were from the South, whereas the floods during during October 1951 occurred with easterly prevailing winds that have a major effect on the coastal areas. As it will be shown in Section 5.2.6, the stability of the atmosphere was different during 


\subsubsection{5-7 January 1977}

On 5-7 January 1977 catastrophic floods affected 5 basins located at the north coast of the studied area. During that days, the recorded $24-\mathrm{h}$ accumulated precipitation was $85 \mathrm{~mm}$ at Tordera, $243 \mathrm{~mm}$ at Girona on 6 January, 163 mm at Cadaquès or $97 \mathrm{~mm}$ at Sant Feliu de Guíxols on 7 January (AEMET). These precipitations produced important damages. On 6 January 1977 floods occurred at Tossa de Mar $\left(120 \mathrm{~m}^{3} \mathrm{~s}^{-1}\right.$ was the peak flow measurement). At Sant Antoni de Calonge a bridge is destroyed and a $240 \mathrm{~m}^{3} \mathrm{~s}^{-1}$ peak flow is estimated by the MOPU. At Girona the same governmental organization estimates $420 \mathrm{~m}^{3} \mathrm{~s}^{-1}$ at the Onyar river, $220 \mathrm{~m}^{3} \mathrm{~s}^{-1}$ at the Ridaura river and 340 $\mathrm{m}^{3} \mathrm{~s}^{-1}$ at the Daró river.

Figure 16 shows the geopotential height (black contour lines), temperature (color contours) and wind field (arrows) at $500 \mathrm{hPa}$ every 6 hours from 5 January 1977 at 18 UTC on until 6 January 1977 at 00 UTC obtained form NOAA's ${ }_{620}$ Twentieth Century Global Reanalysis V2 ensemble mean (Compo et al., 2011). Figures 17, and 18 shows the same variables at 850 and $1000 \mathrm{hPa}$. It can be observed, at $500 \mathrm{hPa}$ (see Fig. 16), a cutoff low with temperatures around $-30^{\circ} \mathrm{C}$ was located over the IP moving South during the whole episode. At $850 \mathrm{hPa}$, low temperatures existed over the Peninsula, but a low located over ${ }_{625}$ North Africa produced easterly winds that brought warm and wet air to the northeastern region of the IP. At the surface (see Fig. 18) easterly, southeasterly winds also brought warm and humid air to the area. The combination of these 
synoptic features did not increase the instability over the area. The calculated values of CAPE by using the Reanalysis data remained below $300 \mathrm{~J} \mathrm{~kg}^{-1}$ in the whole Western Mediterranean (see Section 5.2.6) because surface temperatures were quite low. However, steady precipitation in the northeastern coast of the IP occurred.

\subsubsection{Temporal evolution of the stability indices}

Although some similarities can be found regarding the synoptic situation between episodes occurred in different seasons and affecting different areas within the region under study, in general the stability indices show differences depending on the season, except for the flood occurred on July 1875 (not included in this section).

Taking into account that there are not discrepancies between the calculated stability indices of the same episode, here we focus on CAPE, LI and TT. Figure 19 shows the temporal evolution of CAPE, LI, and TT indices calculated at $42^{\circ} \mathrm{N}-2^{\circ} \mathrm{E}$ for the five episodes, which synoptic situations were presented in detail. It can be observed that summer 1963 episode presents the largest stability indices with maximum $C A P E \sim 1500 \mathrm{~J} \mathrm{~kg}^{-1}, T T \sim 50 \mathrm{~K}$ and $\mathrm{LI}<-6$

K. All these three indices show that the atmosphere was very unstable and severe storms were likely for this episode. During the other summer episode presented in the figure (1897), the instability of the atmosphere was lower, the values of the stability indices were similar to the autumn episodes. By analyzing the horizontal distribution of CAPE and PW during this episode (not shown), a ${ }_{650}$ maximum value of CAPE around $500 \mathrm{~J} \mathrm{~kg}^{-1}$ and PW around $45 \mathrm{~mm}$ exist over 
an area south of the Balearic Islands on 2 July 1897 at 12 UTC. As mentioned, and keeping in mind that the 1897 flood occurred at the beginning of July, one month earlier than the 1963 flood, the flood in this case was a combination of precipitation and snow melting (Trutat, 1898). culated values of CAPE and TT and larger values of $\mathrm{LI}$ at $42^{\circ} \mathrm{N}-2^{\circ} \mathrm{E}$. The differences between the stability indices might be attributed to the different temperatures at the surface and at the upper levels between the two episodes. As was discussed in section 5.2.3 larger surface temperatures and smaller upperatmosphere temperatures were estimated by the Reanalysis for the episode occurring on October 1937. If the horizontal distribution of CAPE is analyzed, during the 1937 (1951) episode CAPE presented a maximum value around 1000 $\mathrm{J} \mathrm{kg}^{-1}$ on 28 October 1937 at 06 UTC (2 October 1951 at $00 \mathrm{UTC}$ ) over the Balearic Islands, southeast to the area under study (not shown). Consequently, instability was lower for these episodes, and the rain and the flood had a larger duration (see Fig. 2). For the January 1977 episode all the stability indices present low instability. By analyzing the horizontal distribution of CAPE, it can be concluded that the atmosphere over the whole western Mediterranean area showed no instability with CAPE $<250 \mathrm{~J} \mathrm{~kg}^{-1}$ during all the days of the flood.

Some authors pointed out that CAPE is a poor predictor of convective properties of the atmosphere (Zipser, 2003). For this reason, Done et al. (2006); Molini et al. (2011) used a convective timescale $\tau_{c}$ to study the stability of 
the atmosphere during for intense rainfall periods. The convective timescale is defined as:

$$
\tau_{c}=\frac{\mathrm{CAPE}}{\left|\frac{d(\mathrm{CAPE})}{d t}\right|}
$$

Done et al. (2006); Molini et al. (2011) show that CAPE generated by largescale processes is balanced (in equilibrium) with the consumption of CAPE by convection for $\tau_{c}<6 \mathrm{~h}$. In this case CAPE remains almost constant. On the other hand, if $\tau_{c}>>6 \mathrm{~h}$ convection is not able to continuously destroy CAPE generated by the large-scale processes and CAPE is not constant. Figure 19d shows the temporal evolution of $\tau_{c}$ for the five selected episodes. It is important to note that there are points not appearing in the figure because $\tau_{c}>100 \mathrm{~h}$. The scale of the vertical axis is limited to avoid some outliers appearing when the denominator of Eq. 1 is very small. As it can be observed, and despite the dispersion of the points, only the episode occurring on January 1977 has $\tau_{c}<6 \mathrm{~h}$ during most of the time. During this episode there is an equilibrium between the generation of CAPE by large-scale processes and convection. For this reason, CAPE stays at lower values (see Fig. 19a). For the other selected episodes, in general $\tau_{c}>6 \mathrm{~h}$. For these episodes $(1897,1937,1951,1963) \mathrm{CAPE}$ ${ }_{690}$ is generated by large-scale processes during several hours and then it decreases suddenly due to the consumption by convection. This fact may occur several times during the same episode (see Fig. 19a). 


\section{Conclusions}

We have analyzed the most catastrophic floods affecting the NE Iberian

695 drological point of view. A systematic methodology has been used to select the episodes, and four additional episodes not selected by the selection procedure for its small extension were additionally included due to their relevance. This selection procedure and the convenient structure of the Prediflood data base allowed us to detect the major floods and the torrential rainfall episodes that caused them in the absence of quantitative data. Indeed, in the best of cases there were rain and stream flow gauges only in a small part of the total area affected, thus making the quantitative data about rainfall and discharge extremely rare and not useful in selecting and characterizing major rain episodes and the floods they caused.

From the selection, and as mentioned by previous studies that used a smaller database, a clear seasonality of the floods is observed. Most of the floods occurred in autumn and none in spring. Summer and winter present approximately the same number of episodes.

By using the NOAA Twentieth Century Reanalysis, we are able to analyze, for all the episodes except 1842, the synoptic conditions that produced the flood and calculate the stability indices during the days of the flood. Most of the episodes were due to a cutoff low in combination with a SE-E low level flow that brought warm and wet air from the Mediterranean basin. In general,

there is a good correspondence between the stability indices and the season 
when occurred the flood. For instance, if the value of CAPE is considered large values are found for the summer episodes, moderate for autumn and low for the winter floods. As it was expected, the duration of the rainfall can be related to the value of CAPE: long duration occurs for low CAPE values and vice versa. The maximum specific peak flow in different catchments of each episode is calculated (when there is enough data) and the relationships between the catchment area, duration of the flood, and CAPE are analyzed regarding the different areas affected by each flood and the season when it occurred. The results can be summarized as follows:

- As previous studies found, the maximum specific peak flow decreases with the catchment area. Autumn floods at the Pyrenees and winter floods at the coast present the lowest specific peak flows.

- The largest specific peak flow occurred in the coastal catchments probably due to the larger supply of water vapor coming from the Mediterranean Sea to this area.

- The maximum specific peak flow decreases with the duration of the rainfall. Summer floods present the smallest duration of the rain fall and the largest peak flows (except 1875 when snow melt played a significant role in producing the flood).

- There seems to be a correlation between maximum CAPE and the highest specific peak flow that a flood can reach, although lower specific peak flows can also occur with high CAPE values. This correlation seems higher for 
summer floods, usually caused by convective events.

We also analyze in detail the synoptic conditions for five representative

740 the flood affected the Pyrenees or the coast based on the synoptic situation and we calculate the temporal evolution of the stability indices at the nearest point of the Reanalysis to the area of the flood. For each episode there is a good correspondence between all the stability indices, and for this reason we focus in present a large increase of CAPE before the flood and a decrease afterwards as it is characteristic of summer thunderstorms, autumn floods $(1937,1951)$ occurred with moderate but variable values of CAPE, whereas for the winter flood (1977) CAPE presented very low values for the whole episode. If $\tau_{c}$ is noticed. During the former episodes there is an imbalance between the CAPE generated by large-scale processes and the destruction by convection and as a consequence CAPE presents high to moderate values and a large variation. For the 1977 winter flood there is an equilibrium between these two processes and CAPE remains very small and almost constant.

This study shows that, despite the low horizontal resolution of the NOAA Reanalysis, these data can be used to analyze the synoptic atmospheric conditions and to study the evolution of the stability indices of historical floods in the NE IP. Additionally, the stability indices, particularly the maximum value 
peak flow.

The proposed methodology, which includes the analysis of the synoptic conditions and stability indices also for historical floods, is very promising and might help to understand the atmospheric processes responsible for floods, even for episodes with scarce rain gauge measurements. To further analyze the atmospheric conditions including additional variables like potential vorticity and increase the horizontal resolution to separate different rainfall areas, mesoscale models fed with the used NOAA Reanalysis or similar data have to be used.

\section{Acknowledgments}

Known and unknown people of the past recorded and preserved valuable information of the floods that made this study possible.

Jordi Pujadas provided four peak flow values (one for the 1994-flood and three for flood occurred on June 2000). Ramon Batalla (RIUS-UdL, Spain) provided one source of peak flow values. Pablo Sangrà (Universidad de Las the synoptic conditions and the stability indices.

Twentieth Century Global Reanalysis V2 data provided by the NOAA/OAR/ESRL PSD, Boulder, Colorado, USA, from their web site at http://www.esrl.noaa.gov/psd/. Support for the Twentieth Century Reanalysis Project dataset is provided by the U.S. Department of Energy.

The authors were financed by Spanish MINECO projects CGL2012-35071 and CGL2012-37416-C04-03, and by the INTERREG EU project FLUXPYR 
EFA 34/08. One of the authors has a pre-doctoral grant from the University of Lleida (Spain).

ACA (2002). Estudi d'actualització de l'avaluació de recursos hídrics de les conques internes de Catalunya i conques Catalanes de l'Ebre. Document de sintesi. Technical Report Agència Catalana de l'Aigua. Departament de Medi Ambient. Generalitat de Catalunya Barcelona, Spain.

ACA (2007). Estudi de tramificació de cabals dels principals cursos fluvials de Catalunya. Technical Report Agència Catalana de l'Aigua. Departament de Medi Ambient i Habitatge. Generalitat de Catalunya Barcelona, Spain.

ACA (2011). Avaluació preliminar del risc d'inundació al districte de conca fluvial de Catalunya. Annex 4. Anàlisi de les inundacions històriques. Technical Report Agència Catalana de l'Aigua. Departament de Medi Ambient. Generalitat de Catalunya Barcelona, Spain.

Albentosa, L. (1983). Precipitaciones excepcionales e inundaciones durante los días 6 al 8 de noviembre de 1982 en Cataluña. In L. Albentosa (Ed.), Las lluvias excepcionales en Cataluña en noviembre de 1982 (pp. 229-273). Estudios geográficos, 44:170/171.

Alonso, S., \& Puigserver, M. (1978). On the energetics of Levante storms. Arch. Meteor. Geophy. A, 27, 105-116.

Balasch, J. C., Remacha, R., Erija, X., \& Sánchez, A. (2007). La riuada del Segre a Lleida. Pagès Editors. 
Balasch, J. C., Ruiz-Bellet, J. L., \& Tuset, J. (2011). Historical flash floods retromodelling in the Ondara River in Tàrrega (NE Iberian Peninsula). Nat. Hazard. Earth Syst. Sci., 11, 3359-3371.

Barnolas, M., \& Llasat, M. C. (2007). A flood geodatabase and its climatological applications: the case of Catalonia for the last century. Nat. Hazard. Earth Syst. Sci., 7, 271-281.

Barredo, J. I. (2007). Major flood disasters in Europe: 1950-2005. Nat. Hazards, 42, 125-148.

Barrera-Escoda, A., \& Llasat, M. C. (2015). Evolving flood patterns in a Mediterranean region (1301-2012) and climatic factors - the case of Catalonia. Hydrol. Earth Syst. Sci., 19, 465-483.

Barriendos, M., \& Martín-Vide, J. (1998). Secular climatic oscillations as indicated by catastrophic floods in the Spanish Mediterranean coastal area (14th19th centuries). Nat. Hazards Earth Syst. Sci., 38, 473-491.

Barriendos, M., \& Pomés, J. (1993). L'aigua a Mataró: Inundacions i recursos hídrics (ss. XVIII-XX). Mataró, Spain: Caixa d'Estalvis Laietana.

Barriendos, M., Ruiz-Bellet, J. L., Tuset, J., Mazon, J., Balasch, J. C., Pino, D., \& Ayala, J. L. (2014). The "Prediflood" database of historical floods in Catalonia (NE Iberian Peninsula) AD 1035-2013, and its potential applications in flood analysis. Hydrol. Earth Syst. Sci., 18, 4807-4823. 
Becat, J., \& Soutadé, G. (1993). Inundacions catastròfiques i polítiques de prevenció a la Mediterranea nord-occidental. Servei Geològic de Catalunya.

Benito, G., Ouarda, T. B. M. J., \& Bárdossy, A. (2005). Applications of paleoflood hydrology and historical data in flood risk analysis. J. Hydrol., 313, $1-2$.

Borga, M., Anagnostou, E. N., Blöschl, G., \& Creutin, J.-D. (2011). Flash flood 830 forecasting, warning and risk management: the HYDRATE project. Environ. Sci. Policy, 14, 834-844.

Brázdil, R., Kundzewicz, Z. W., \& Benito, G. (2006). Historical hydrology for studying flood risk in Europe. Hydrolog. Sci. J., 51, 739-4764.

Calder, I. R. (2007). Forest and water. Ensuring forest benefits outweigh water costs. Forest Ecol. Manag., 251, 110-120.

Casado, M. J., Pastor, M. A., \& Doblas-Reyes, F. J. (2010). Links between circulation types and precipitation over Spain. Phys. Chem. Earth, 35, 437447.

Casas, M. C. (2005). Análisis espacial y temporal de las lluvias extremas en Catalunya. Modelización y clasificación objetiva. Ph.D. thesis University of Barcelona.

Castro, A., Vidal, M. I., Calvo, A. I., Fernández-Raga, M., \& Fraile, R. (2011). May the NAO index be used to forecast rain in Spain? Atmos., 24, 251-265. 
Codina, B., Aran, M., Young, S., \& Redaño, A. (1997). Prediction of a mesoscale convective system over Catalonia (Northeastern Spain) with a nested numerical model. Meteorol. Atmos. Phys., 62, 9-22.

Compo, G. P., Whitaker, J. S., \& Sardeshmukh, P. D. (2006). Feasibility of a 100 year reanalysis using only surface pressure data. B. Am. Meteorol. Soc., $87,175-190$.

${ }_{850}$ Compo, G. P., Whitaker, J. S., Sardeshmukh, P. D., Matsui, N., Allan, R. J., Yin, X., Gleason, B. E., Vose, R. S., Rutledge, G., Bessemoulin, P., Brnnimann, S., Brunet, M., Crouthamel, R. I., Grant, A. N., Groisman, P. Y., Jones, P. D., Kruk, M., Kruger, A. C., Marshall, G. J., Maugeri, M., Mok, H. Y., Nordli, Ross, T. F., Trigo, R. M., Wang, X. L., Woodruff, S. D., \& Worley, S. J. (2011). The Twentieth Century Reanalysis Project. Q. J. Roy. Meteor. Soc., 137, 1-28. doi:10.1002/qj.776.

Conacher, A., \& Sala, M. (1998). Land degradation in Mediterranean environment of the World: nature and extent. Chichester, New York: Wiley.

Coy i Cotonat, A. (1906). Sort y Comarca Noguera Pallaresa. Barcelona, Spain: 860 Vda. de José Cunill.

Cuadrat, J. M., Saz, M. A., Vicente-Serrano, S. M., \& González-Hidalgo, J. C. (2007). Water resources and precipitation trends in Aragon. Int. J. Water Resour. D., 23, 107-123.

Dayan, U., Nissen, K. M., \& Ulbrich, U. (2015). Review article: Atmospheric 
conditions inducing extreme precipitation over Eastern and Western Mediterranean. Nat. Hazard. Earth Syst. Sci., 15, 2525-2544.

Delrieu, G., Ducrocq, V., Gaume, E., Nicol, J., Payrastre, O., Yates, E., Kirstetter, P.-E., Andrieu, H., Ayral, P.-A., Bouvier, C., Creutin, J.-D., Livet, M., Anquetin, S., Lang, M., Neppel, L., Obled, C., Parent-du Châtelet, J., Saulnier, G.-M., Walpersdorf, A., \& Wobrock, W. (2005). The catastrophic flash-flood event of 8-9 September 2002 in the Gard region, France: a first case study for the Cévennes-Vivarais Mediterranean Hydrometeorological Observatory. J. Hydrometeorol., 6, 34-52.

Dieulafoy, M. (1875). Memoria sobre la inunadación de la ciudad de Tolosa en la última crecida del Garona. Revista de Obras Públicas, 23, 209-212.

Done, J. M., Craig, G. C., Gray, S. L., Clark, P. A., \& Gray, M. E. B. (2006). Mesoscale simulations of organized convection: Importance of convective equilibrium. Q. J. Roy. Meteor. Soc., 132, 737-756.

Doswell III, C. A. (2001). Severe convective stroms. American Meteorological 880 Society.

Doswell III, C. A., \& Rasmussen, E. N. (1994). The effect of neglecting the virtual temperature correction on CAPE calculations. Weather Forecast., 9, $625-629$.

Dünheloh, A., \& Jacobeit, J. (2003). Circulation dynamics of Mediterranean precipitation variability 1948-98. Int. J. Climatol., 23, 1843-1866. 
Dunne, T., \& Black, R. D. (1970). Partial area contributions to storm runoff in a small New England watershed. Water Resour. Res., 6, 1296-1311.

Dunne, T., \& Leopold, L. B. (1978). Water in environment planning. San Francisco (CA), USA: Freeman.

Esteban, P., Jones, P. D., Martín-Vide, J., \& Mases, M. (2005). Atmospheric circulation patterns related to heavy snowfall days in Andorra, Pyrenees. Int. J. Climatol., 25, 319-329.

Fernández-Montes, S., Seubert, S., Rodrigo, F. S., Rasilla Álvarez, D. F., Hertig, E., Esteban, P., \& Philipp, A. (2014). Circulation types and extreme precipitation days in the Iberian Peninsula in the transition seasons: Spatial links and temporal changes. Atmos. Res., 138, 41-58.

Fontseré, E., \& Galceran, F. (1938). Les inundacions d'octubre de 1937 a l'Alt Pirineu. Memòries. Technical Report Servei Meteorològic de Catalunya.

Francés, F. (2000). Consecuencias de la lluvia del 10 Junio 2000 sobre el comportamiento hidrológico de la Riera de Magarola y sus afluentes. In Proceedings of the VI Jornades de Meterologia Eduard Fontseré. ACAM. URL: http://acam.cat/node/100.

Gallart, F., \& Berliner, P. (2011). Hydrology of the Mediterranean system. In Y. Birot, \& C. Gracia (Eds.), Water for Forest and People in the Mediterranean Region. A challenging balance. What Science Can Tell Us. European Forest Institute. 
Gallart, F., \& Llorens, P. (2004). Observations on land cover changes and water resources in the headwaters of the Ebro catchment, Iberian Peninsula. Phys. Chem. Earth, 29, 769-773.

Galway, J. G. (1956). The lifted index as a predictor of latent instability. $B$. Am. Meteorol. Soc., 37, 528-529.

García-Ruiz, J. M., White, S. M., Martí, C., Valero, B., Errea, M. P., \& Gómez-Villar, A. (1996). La catástrofe del barranco de Arás (Biescas, Pirineo aragonés) y su contexto espacio-temporal. Technical Report Consejo Superior de Investigaciones Científicas Zaragoza, Spain.

García-Ruiz, J. M., White, S. M., Martí-Bono, C., Valero, B., Errea, M. P., \& Gómez-Villar, A. (2004). La avenida del barranco de Arás y los riesgos hidrológicos en el Pirineo central español. In Peña, J. L.; Longares, L. A.; Sánchez-Fabre (Ed.), Geografía Física de Aragón. Aspectos generales y temáticos. Zaragoza, Spain: Universidad de Zaragoza e Institución Fernando el Católico. URL: http://age.ieg.csic.es/fisica/docs/012.pdf.

Gaume, E., Bain, V., Bernardara, P., Newinger, O., Barbuc, M., Bateman, A., Blaskovicova, L., Blöschl, G., Borga, M., Dumitrescu, A., Daliakopoulos, I., García, J., Irimescu, A., Kohnova, S., Koutroulis, A., Marchi, L., Matreata, ${ }_{925}$ S., Medina, V., Preciso, E., Sempere-Torres, D., Stancalie, G., Szolgay, J., Tsanis, I., Velasco, D., \& Viglione, A. (2009). A compilation of data on European flash floods. J. Hydrol., 367, 70-78.

Georgakakos, K. P., \& Hudlow, M. D. (1984). Quantitative precipitation forecast 
techniques for use in hydrologic forecasting. B. Am. Meteorol. Soc., 65, 11861200.

González-Hidalgo, J. C., López-Bustins, J.-A., Štepánek, P., Martín-Vide, J., \& de Luis, M. (2009). Monthly precipitation trends on the Mediterranean fringe of the Iberian Peninsula during the second-half of the twentieth century (1951-2000). Int. J. Climatol., 29, 1415-1429.

${ }_{935}$ Goodess, C. M., \& Jones, P. D. (2002). Links between circulation and changes in the characteristics of Iberian rainfall. Int. J. Climatol., 22, 1593-1615.

Gusman, A. J. (2011). Sediment/debris bulking factors and post-fire hydrology for Ventura County. Technical Report West Consultants, Inc. San Diego (CA), USA. URL: http://www.asce-sbriv.org/sw_committee/ documents/Bulking_Factor_Study\%20_Final_Report_6_24_11.pdf.

Hewlett, J. D., \& Hibbert, A. R. (1967). Factors affecting the response of small watersheds to precipitation in humid areas. Forest Hydrol., (pp. 275-290).

Hooke, J. M. (2006). Human impacts on fluvial systems in the Mediterranean region. Geomorphology, 79, 311-335.

Junta d'Aigües (1995). Anuari de dades hidrològiques 1987-88/1988-89/198990. Technical Report Departament de Política Territorial i Obra Pública. Generalitat de Catalunya Barcelona, Spain.

La Vanguardia (1901a). Notas Locales. 22 September. [Newspaper; online]. 
La Vanguardia (1901b). Las inundaciones del Llobregat. 23 September. [Newspaper; online].

Lafore, J. P., Stein, J., Asencio, N., Bougeault, P., Ducrocq, V., Duron, J., Fischer, C., Hériel, P., Mascart, P., Masson, V., Pinty, J. P., Redelsperger, J. L., Richard, E., \& Vilà-Geurau de Arellano, J. (1998). The Meso-NH atmospheric simulation system. Part I: adiabatic formulation and control simulations. Ann. Geophys., 16, 90-109.

Lana, X., Martínez, M. D., Serra, C., \& Burgueño, A. (2004). Spatial and temporal variability of the daily rainfall regime in Catalonia (Northeastern Spain), 1950-2000. Int. J. Climatol., 24, 613-641.

Lang, M., \& Coeur, D. (2014). Les inondations remarquables en France. Versailles, France: Éditions Quae.

Lin, Y.-L., Chiao, S., Wang, T.-A., Kaplan, M. L., \& Werglarz, R. P. (2001). Some common ingredients for heavy orographic rainfall. Weather Forecast., $16,633-660$.

Llasat, M. C. (1990). Influencia de la orografía y de la inestabilidad convectiva en la distribución espacial de lluvias extremas en Cataluña. Acta Geol. Hisp., 25, 197-208.

Llasat, M. C., Barriendos, M., Barrera, A., \& Rigo, T. (2005). Floods in Catalonia (NE Spain) since the 14th Century. Climatological and meteorological aspects from historical documentary sources and old instrumental records. $J$. Hydrol., 313, 32-47. 
Llasat, M. C., Llasat-Botija, M., Prat, M. A., Porcú, F., Price, C., Mugnai, A., Lagouvardos, V., K.and Kotroni, Katsanos, D., Michaelides, S., Yair, Y., Savvidou, K., \& Nicolaides, K. (2010). High-impact floods and flash floods in Mediterranean countries: the FLASH preliminary database. Adv. Geosci., $23,47-55$.

Llasat, M. C., López, L., Barnolas, M., \& Llasat-Botija, M. (2008). Flash-floods in Catalonia: the social perception in a context of changing vulnerability. Adv. Geosci., 17, 63-70.

Llasat, M. C., Martín, F., \& Barrera, A. (2007). From the concept of "Kaltlufttropfen" (cold air pool) to the cut-off low. The case of September 1971 in Spain as an example of their role in heavy rainfalls. Meteorol. Atmos. Phys., $96,43-60$.

Llasat, M. C., Rigo, T., \& Barriendos, M. (2003). The Montserrat-2000 flash flood event: a comparison with the floods that have occurred in the northeastern Iberian Peninsula since the 14th century. J. Climatol., 23, 453-469.

López-Bustos, A. (1972). Antecedentes para una historia de avenidas del río Ebro. Revista de Obras Públicas, 3083, 191-204.

López-Bustos, A. (1980). Antecedentes para una historia de avenidas de los ríos del Pirineo Oriental. Revista de Obras Públicas, 3180, 369-383. peninsulares. Revista de Obras Públicas, 3190, 179-192. 
Mapes, B. E. (1993). Gregarious tropical convection. J. Atmos. Sci., 50, 20262037.

Marchi, L., Borga, M., Preciso, E., \& Gaume, E. (2010). Characterisation of selected extreme flash floods in Europe and implications for flood risk management. J. Hydrol., 394, 118-133.

Martín-Vide, J. (1985). Pluges i inundacions a la mediterrània. Ketres.

Martín-Vide, J., \& López-Bustins, J. A. (2006). The Western Mediterranean Oscillation and rainfall in the Iberian Peninsula. J. Climatol., 26, 1455-1475.

Martín-Vide, J., Sánchez-Lorenzo, A., López-Bustins, J. A., Cordobilla, M. J., García-Manuel, A., \& Raso, J. M. (2008). Torrential rainfall in Northeast of the Iberian Peninsula: Synoptic patterns and WeMO influence. Adv. Sci. Res., 2, 99-105.

Martín-Vide, J. P. (2002). Estudio de la inundabilidad del río Garona y sus afluentes en el Vall d'Aran. Technical Report Universitat Politécnica de Catalunya.

Mazon, J., Balasch, J. C., Barriendos, M., Ruiz-Bellet, J. L., Tuset, J., \& Pino, D. (2014). Meteorological reconstruction of major floods in early instrumental period in Catalonia (NE Iberian Peninsula). In 14th EMS Annual Meeting. URL: http://presentations.copernicus.org/EMS2014-141_ presentation.pdf.

Mazon, J., \& Pino, D. (2012). The greatest recent flood in Spain: a WRF 
simulation of the 1962 Vallès flood event. In 14th EGU Plinius Conference on Mediterranean Storms and MEDEX Final Conference. European Geosciences Union. URL: http://meetingorganizer.copernicus. org/Plinius14/Plinius14-48.pdf.

Millán, M. M. (2014). Extreme hydrometeorological events and climate change predictions in Europe. J. Hydrol., 518, 206-234.

Miller, R. C. (1972). Notes on analysis and severe storm forecasting procedures of the Air Force Global Weather Central. Technical Report 200(R) Air Weather Service, Scott Air Force Basem IL 62225.

Molini, L., Parodi, A., Rebora, N., \& Craig, G. C. (2011). Classifying severe rainfall events over Italy by hydrometeorological and dynamical criteria. $Q$. J. Roy. Meteor. Soc., 137, 148-154. doi:10.10002/qj.741.

1025 Montalbán, M., Berga, L., Heras, R., Novoa, M., \& Témez, J. R. (1994). Recomanacions sobre mètodes d'estimació d'avingudes màximes. Technical Report Junta d'Aigües. Departament de Política Territorial i Obra Pública. Generalitat de Catalunya Barcelona, Spain.

MOPU (1983). Estudio de Inundaciones Históricas. Mapa de riesgos potenciales. Cuenca del Pirineo Oriental. Technical Report Dirección General de Obras Hidráulicas. Ministerio de Obras Públicas y Urbanismo (MOPU) Madrid, Spain.

Muñoz-Díaz, D., \& Rodrigo, F. S. (2006). Seasonal rainfall variations in Spain 
(1912-2000) and their links to atmospheric circulation. Atmos. Res., 81, 94110.

Nguyen, C. C., Gaume, E., \& Payrastre, O. (2014). Regional flood frequency analyses involving extraordinary flood events at ungauged sites: further developments and validations. J. Hydrol., 508, 385-396.

Norbiato, D., Borga, M., Degli Esposti, S., Gaume, E., \& Anquetin, S. (2008). $1040 \quad$ Flash flood warning based on rainfall thresholds and soil moisture conditions: an assessment for gauged and ungauged basins. J. Hydrol., 362, 274-290.

Novoa, M. (1981). Precipitaciones extremas en la cuenca del Pirineo Oriental. Causas, efectos y previsión. Technical Report Ministerio de Obras Públicas y Urbanismo Madrid, Spain.

1045 Novoa, M. (1987). Inundaciones en la cuenca del Pirineo Oriental. In L. Berga, \& J. Dolz (Eds.), Avenidas. Sistemas de previsión y alarma (pp. 375-397). Madrid, Spain: Colegio de Ingenieros de Caminos, Canales y Puertos.

Olcina, J., \& Ayala-Carcedo, F. J. (2002). Riesgos Naturales. Barcelona, Spain: Editorial Ariel.

Pou, A. (1994). Cronologia de les inundacions alt-empordaneses documentades per la premsa local. In Annals de l'Institut d'Estudis Empordanesos (pp. 203-226). Figueres, Spain volume 27.

Pujadas, J. (1994). Mapa de riscos d'inundació i riscos associats de La Riba, 
riu Francolí. Technical Report Departament de Política Territorial i Obres Públiques. Generalitat de Catalunya Barcelona, Spain.

Pujadas, J. (2015). Hidrologia de camp de l'avinguda de 10 de Juny de 2000 a Catalunya Central. Technical Report.

Ramis, C., Homar, V., Amengual, A., Romero, R., \& Alonso, S. (2013). Daily precipitation records over mainland Spain and the Balearic Islands. Nat. Hazards Earth Syst. Sci., 13, 2483-2491.

Ramis, C., Llasat, M. C., Genovés, A., \& Jansà, A. (1994). The October-1987 floods in Catalonia: synoptic and mesoscale mechanisms. Meteorol. Apps., 1, $337-350$.

Ramis, C., Romero, R., Homar, V., Alonso, S., \& Alarcón, M. (1998). Diagnosis and numerical simulation of a torrential precipitation event in Catalonia, Spain. Meteorol. Atmos. Phys., 69, 1-21.

Rodó, X., Baert, E., \& Comin, F. A. (1997). Variations in seasonal rainfall in Southern Europe during the present century: Relationships with the North Atlantic Oscillation and the El Niño-Southern Oscillation. Clim. Dynam., 13, $275-284$.

Romero, R., \& Ramis, C. (2002). Torrential daily rainfall patterns in Mediterranean Spain and associated meteorological settings. Thetys, 2, 1-16.

Romero, R., Ramis, C., \& Guijarro, J. A. (1999a). Daily rainfall patterns in the 
Spanish Mediterranean area: An objective classification. Int. J. Climatol., $19,95-112$.

Romero, R., Sumner, G., Ramis, C., \& A., G. (1999b). A classification of the atmospheric circulation patterns producing significant rainfall in the Spanish Mediterranean area. Int. J. Climatol., 19, 765-785.

Rozalis, S., Morin, E., Yair, Y., \& Price, C. (2010). Flash flood prediction using an uncalibrated hydrological model and radar rainfall data in a Mediterranean watershed under changing hydrological conditions. J. Hydrol., 394, 245-255.

Ruiz-Bellet, J. L., Balasch, J. C., Tuset, J., Barriendos, M., Mazon, J., \& Pino, D. (2015). Historical, hydraulic, hydrological and meteorological reconstruction of 1874 Santa Tecla flash floods in Catalonia (NE Iberian Peninsula). $J$. Hydrol., 524, 279-295.

Sala, M., \& Inbar, M. (1992). Some hydrologic effects of urbanization in Catalan rivers. Catena, 19, 363-378.

Salvadó, J. (1996). La Rubinada de Santa Tecla de 1874 a Tàrrega. Technical Report Natan Estudis, 6 Ajuntament de Tàrrega. M., Huang, X.-Y., W., W., \& Powers, J. G. (2008). A Description of the Advanced Research WRF Version 3. Technical Report TN-475+STR NCAR.

Solé Sabarís, L. (1958). Geografía de Catalunya. Edit. Aedos. 
Tomás, A. (1963). Causas meteorológicas de las inundaciones del Bajo Vallés,

Est. Geogr., 91, 137-146.

Tomás, A. (1972). Las inundaciones de Septiembre de 1971 y sus causas. Misc. Barcin., 32, 125-141.

Trapero, L., Bech, J., Duffourg, F., Esteban, P., \& Lorente, J. (2013a). Mesoscale numerical analysis of the historical November 1982 heavy precipitation event over Andorra (Eastern Pyrenees). Nat. Hazard. Earth Syst. Sci., 10, 2969-2990.

Trapero, L., Bech, J., \& Lorente, J. (2013b). Numerical modelling of heavy precipitation events over Eastern Pyrenees: Analysis of orographic effects. Atmos. Res., 123, 368-383.

Trutat, M. (1898). Inondations dans les Pyrénées Centrales. (Juillet-Octobre 1897). Bull. Soc. Geogr. Toulouse, 3, 177-214.

Tudurí, E., \& Ramis, C. (1997). The environments of significant convective events in the Western Mediterranean. Weather Forecast., 12, 294-306.

Tuset, J. (2008). La riuada del 6 i 7 de novembre de 1982: aplicació d'un model hidrometeorològic per a l'obtenció del patró espacial $i$ temporal de la precipitació. Master's thesis Universidad de Barcelona Barcelona, Spain.

Velasco, E. (2000). Les riuades del 10/06/00 a les conques vessants al Llobregat. 
In Proceedings of the VI Jornades de Meterologia Eduard Fontseré. ACAM.

Vergés, R. (1992). Les obres hidàuliques. In D. Saurí (Ed.), Les inundacions. Quaderns d'Ecologia Aplicada no 14 (pp. 65-87). Lleida, Spain: Diputació de Barcelona.

Weisman, M. L., \& Klemp, J. B. (1986). Characterisitcs of isolated convective ${ }_{1120} \quad$ stroms. In P. S. Ray (Ed.), Mesoscale Meteorology and Forecasting (pp. 331358). Amer. Meteor. Soc.

Whitaker, J. S., Compo, G. P., Wei, X., \& Hamill, T. M. (2004). Reanalysis without radiosondes using ensemble data assimilation. Mon. Weather Rev., 132, 1190-1200.

Zipser, E. J. (2003). Some views on 'Hot Towers' after 50 years of tropical field programs and two years of TRMM data. Meteor. Mon., 29, 49-58. 


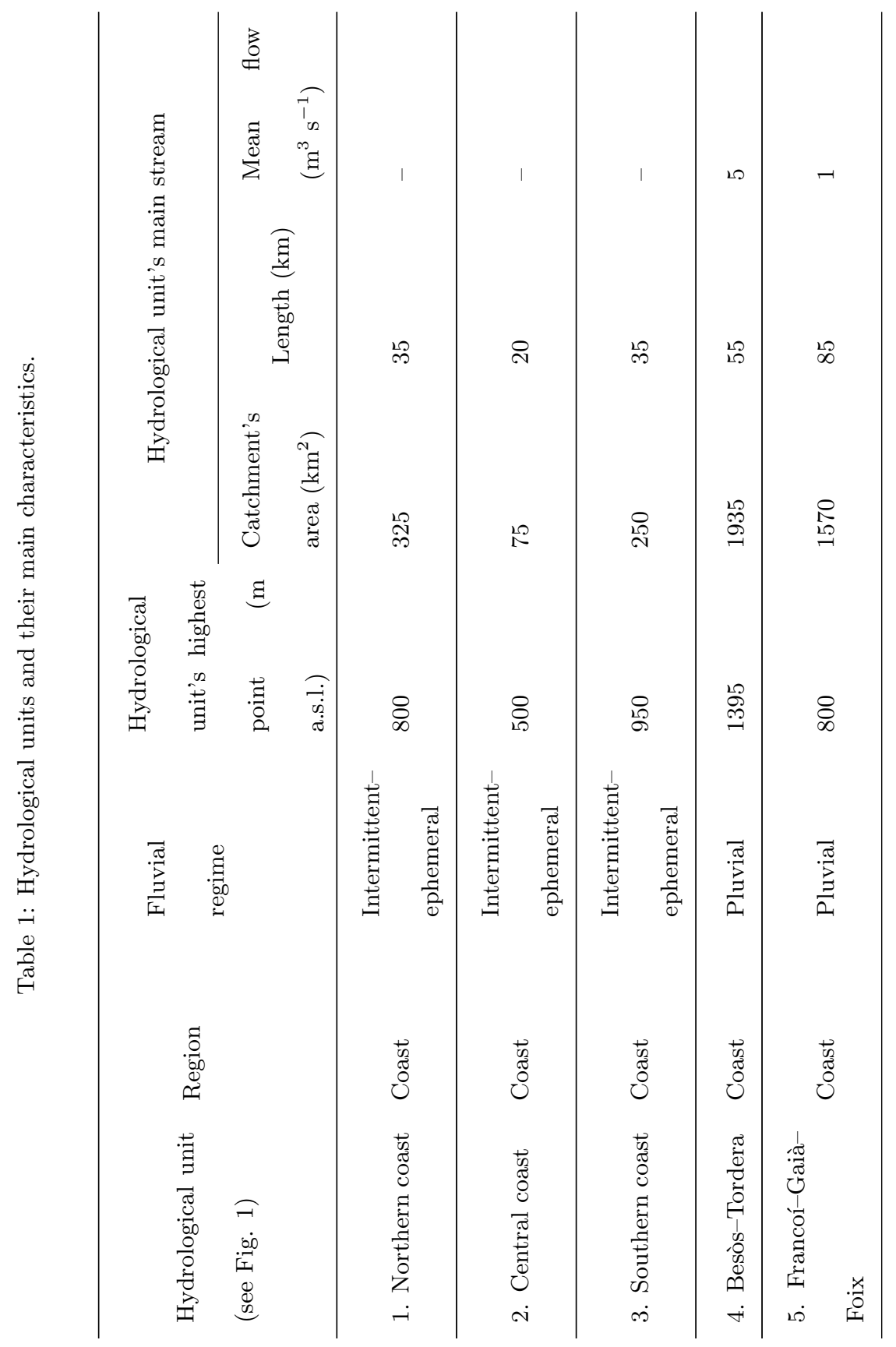




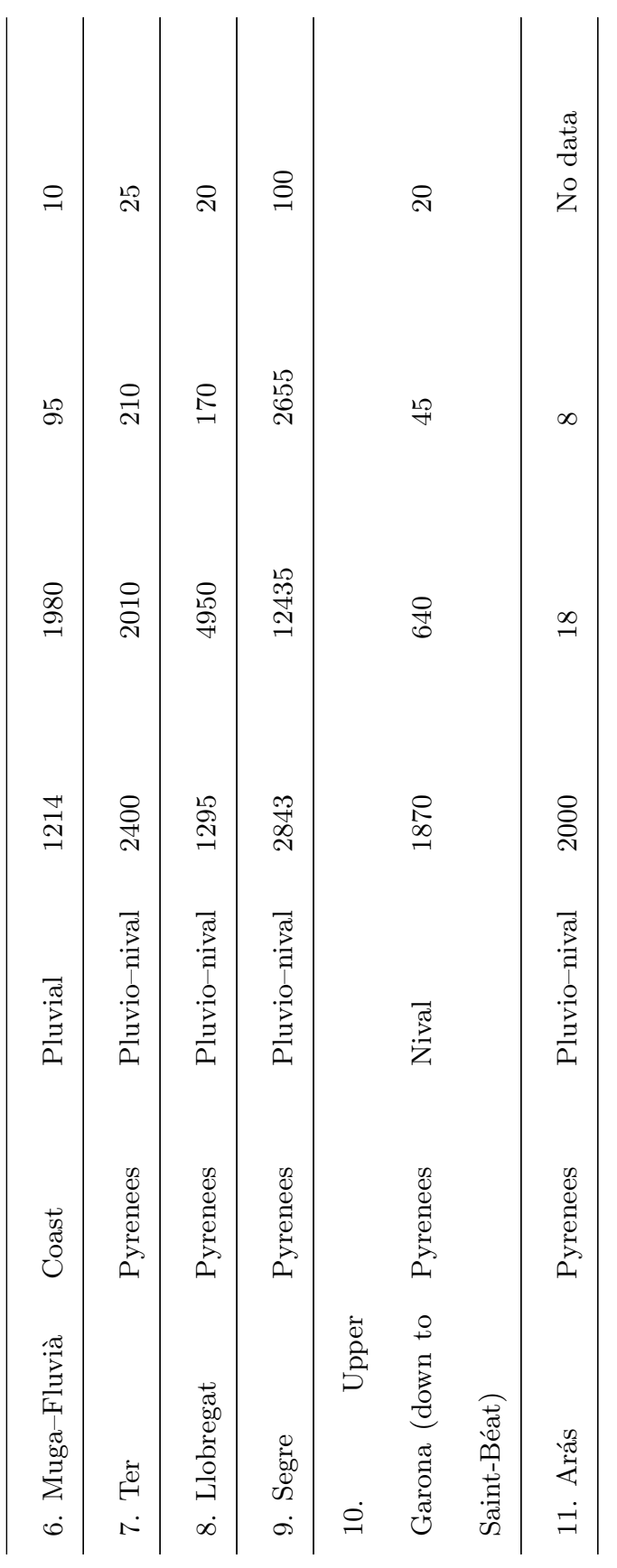




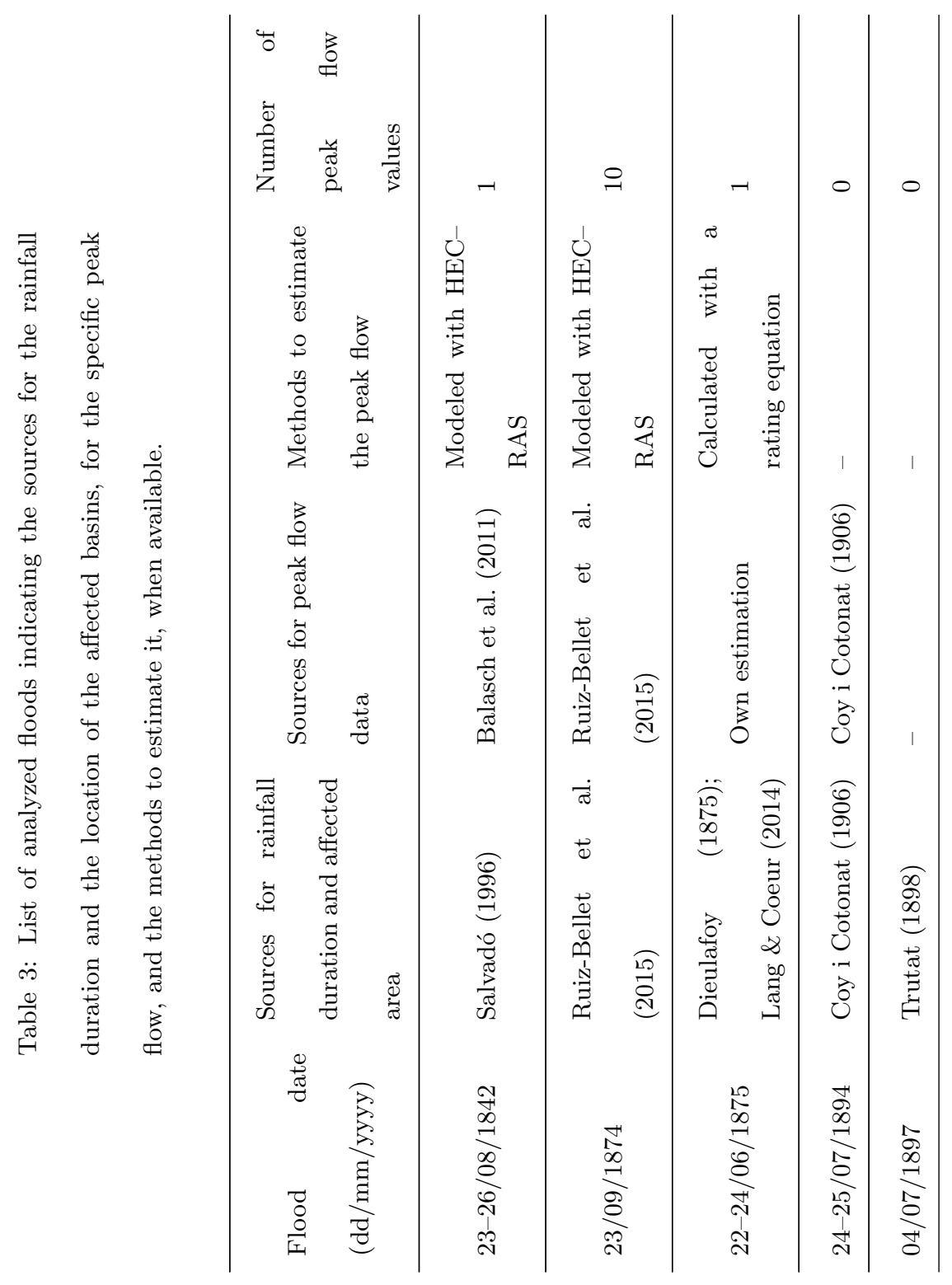




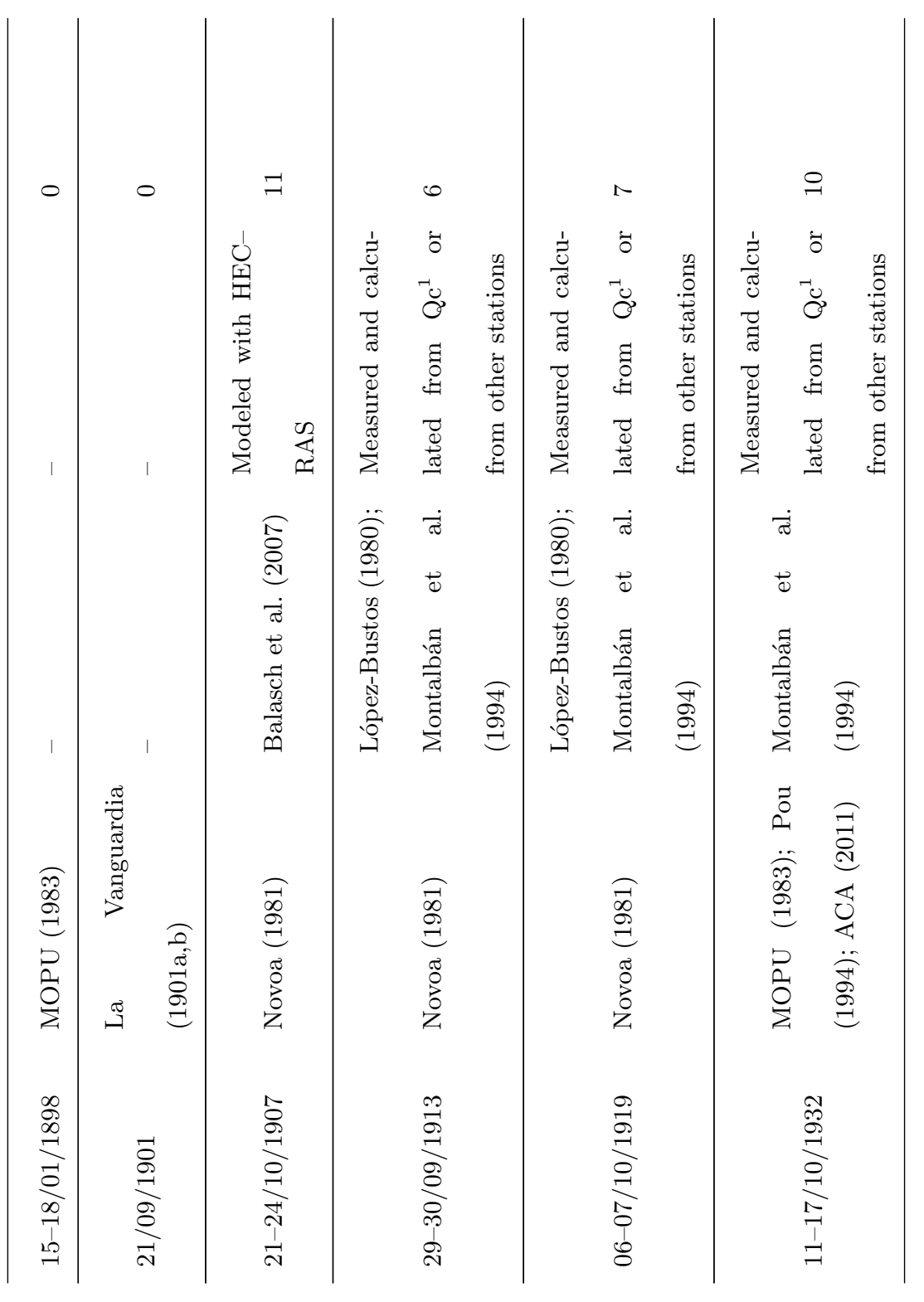




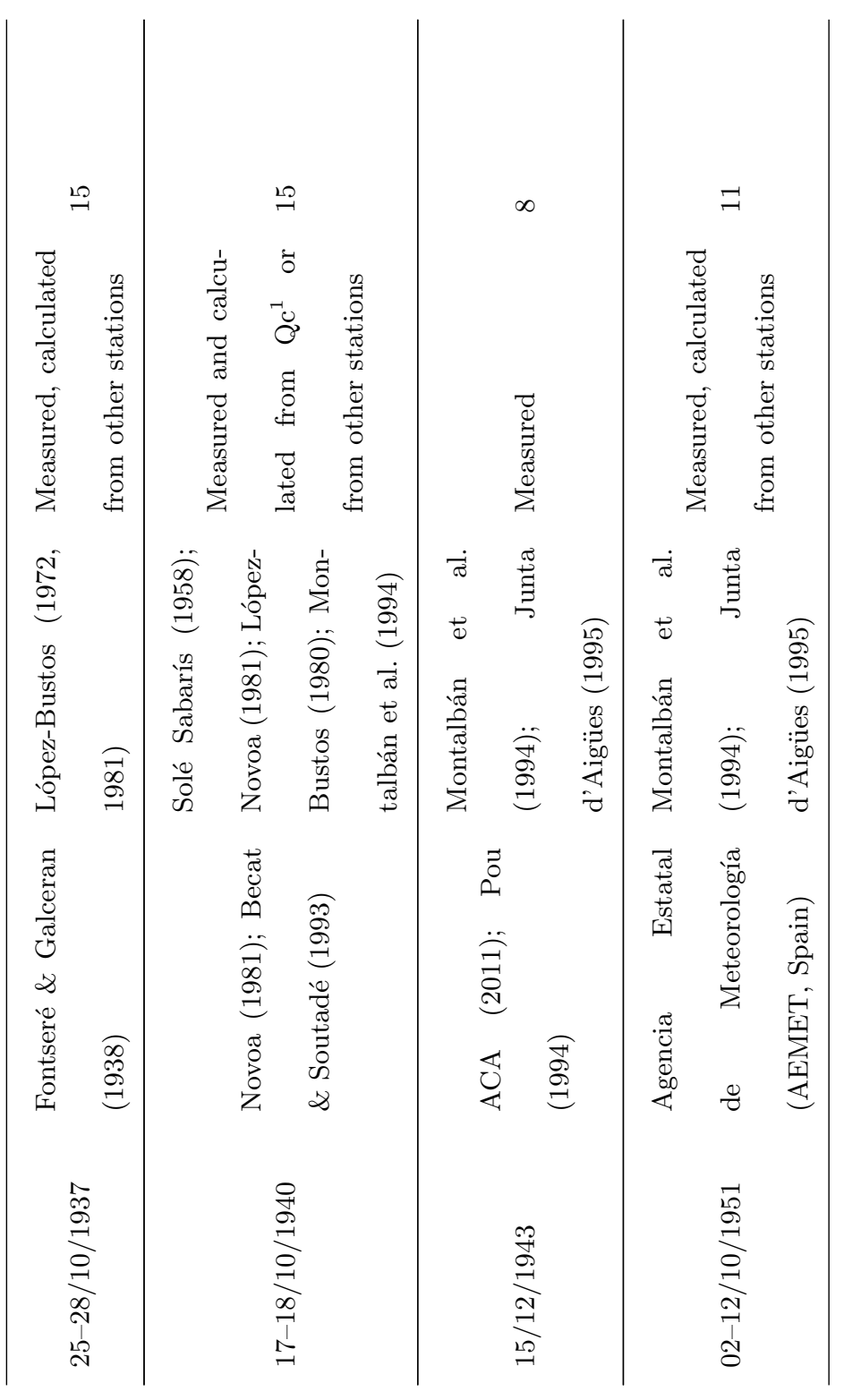




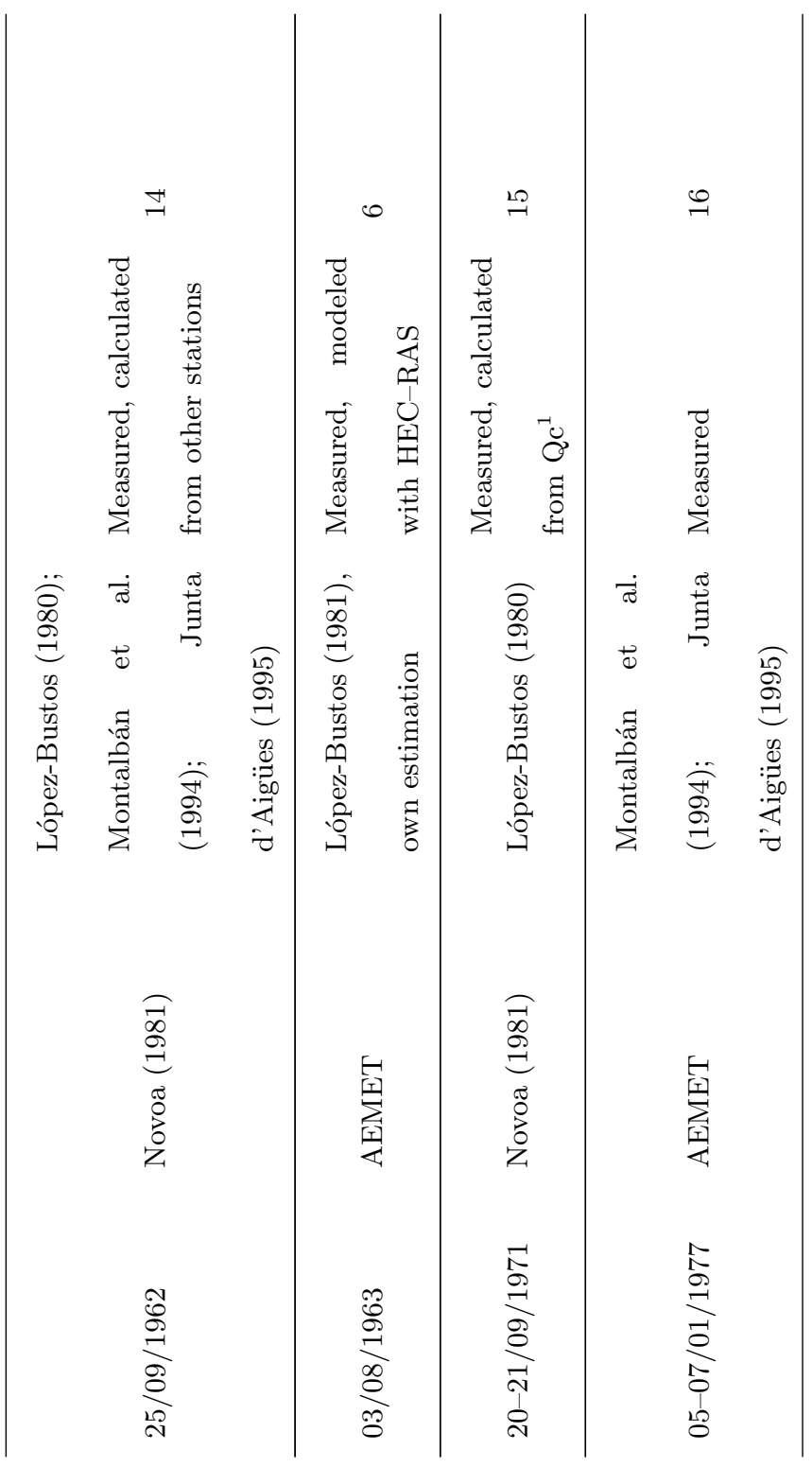

61 


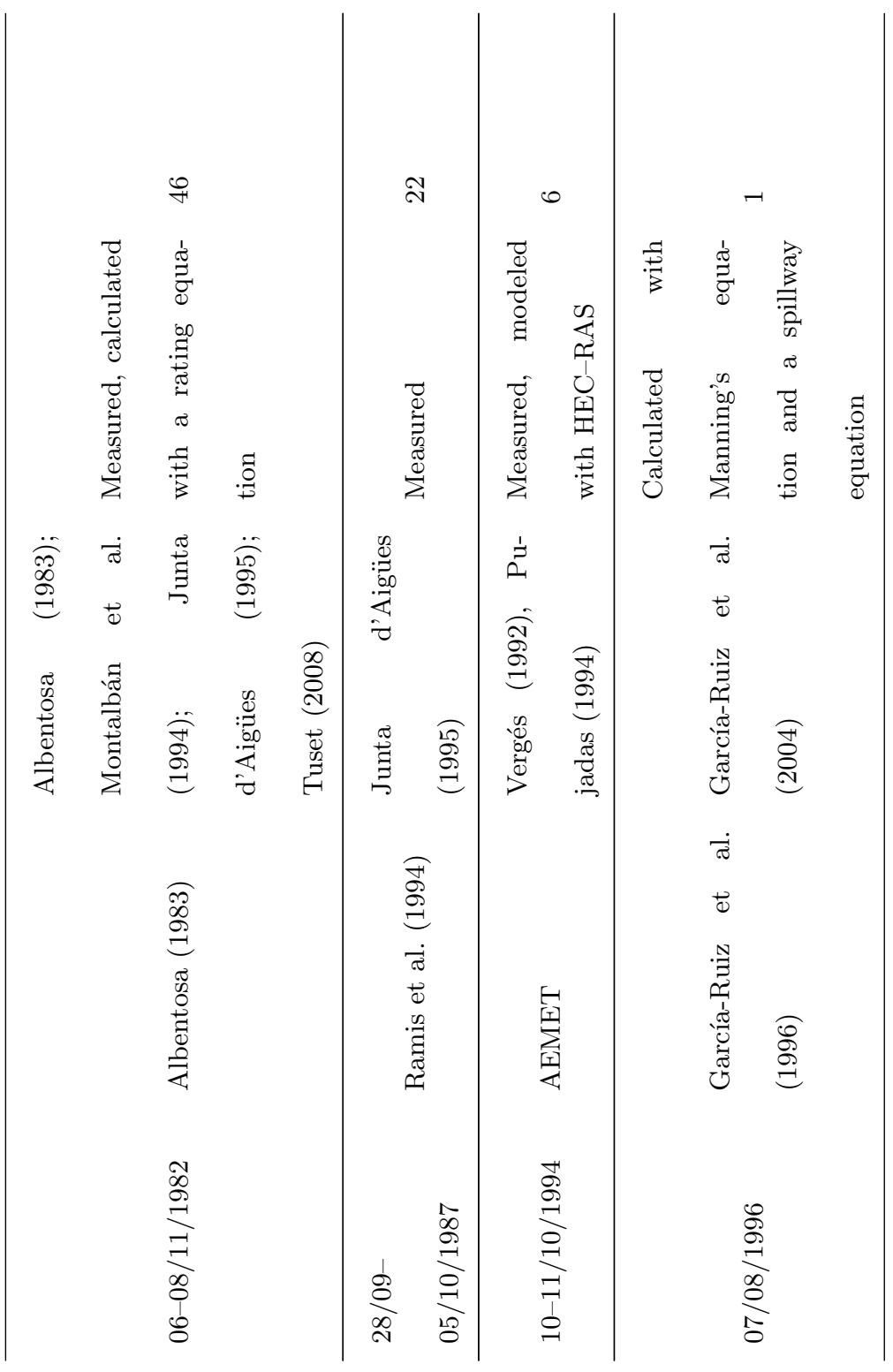




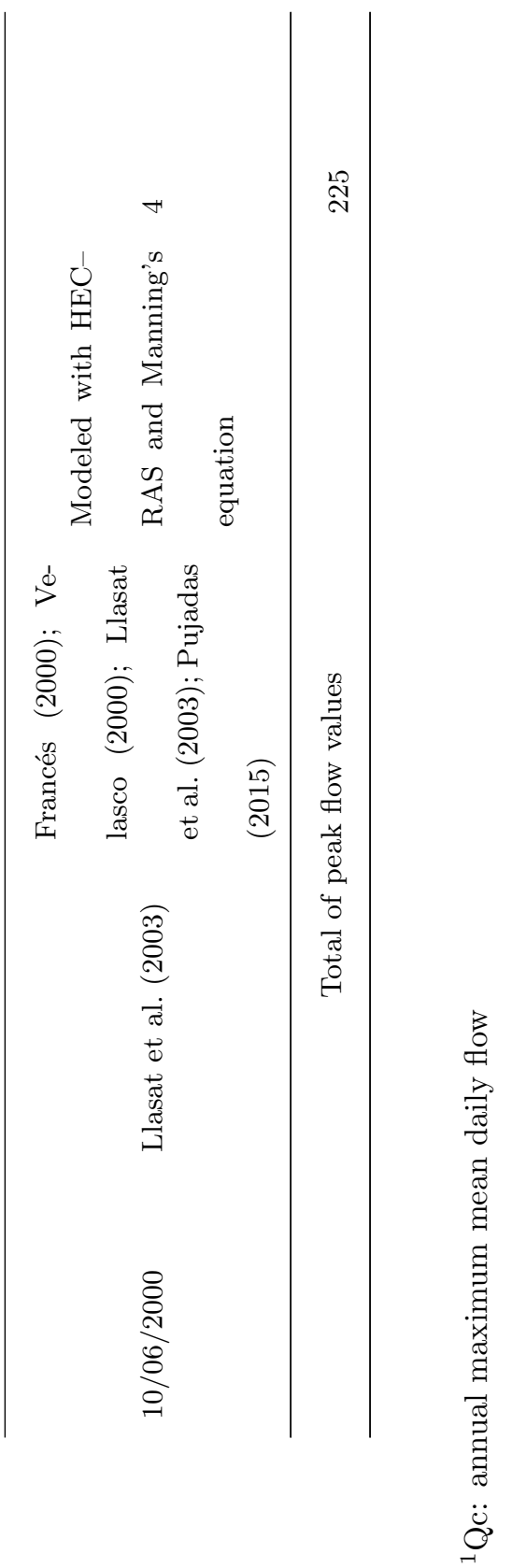




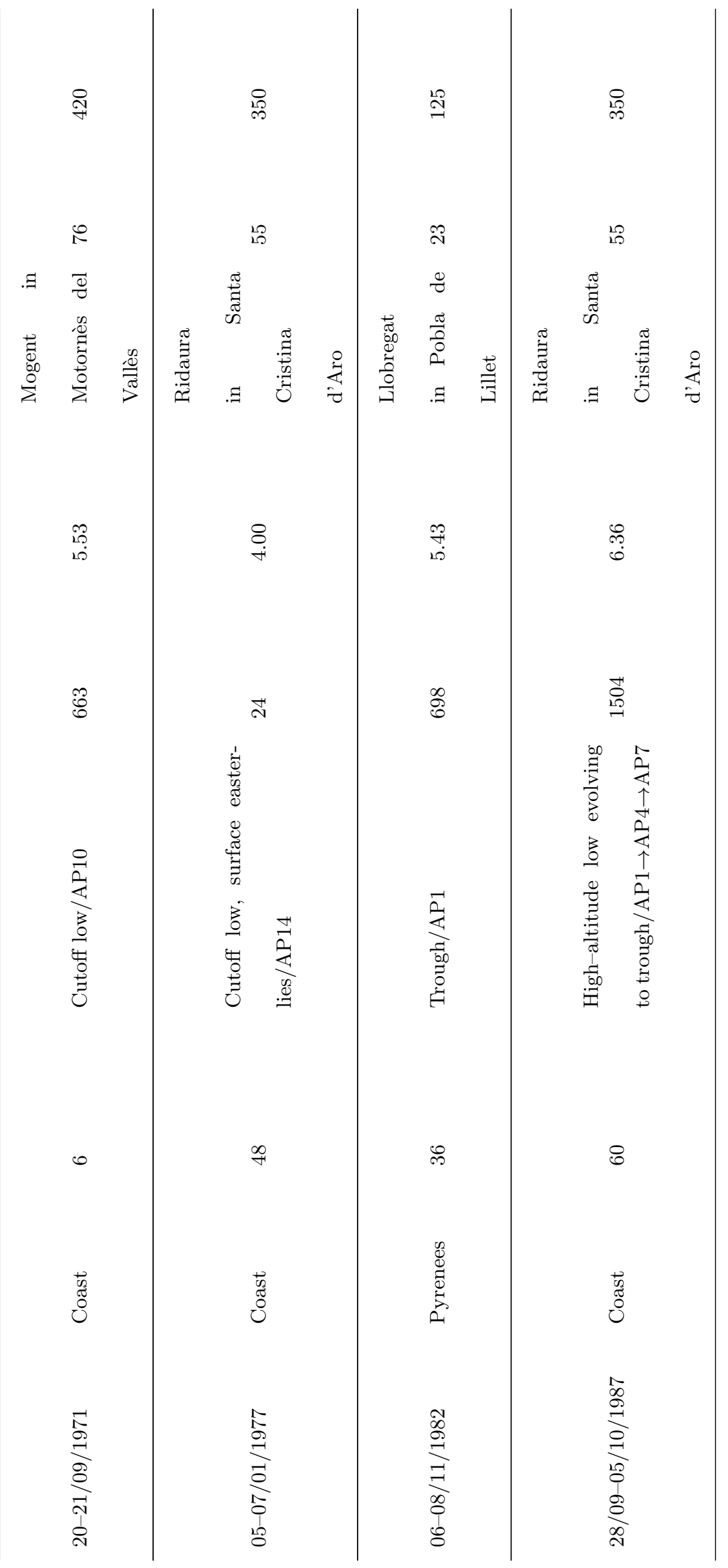




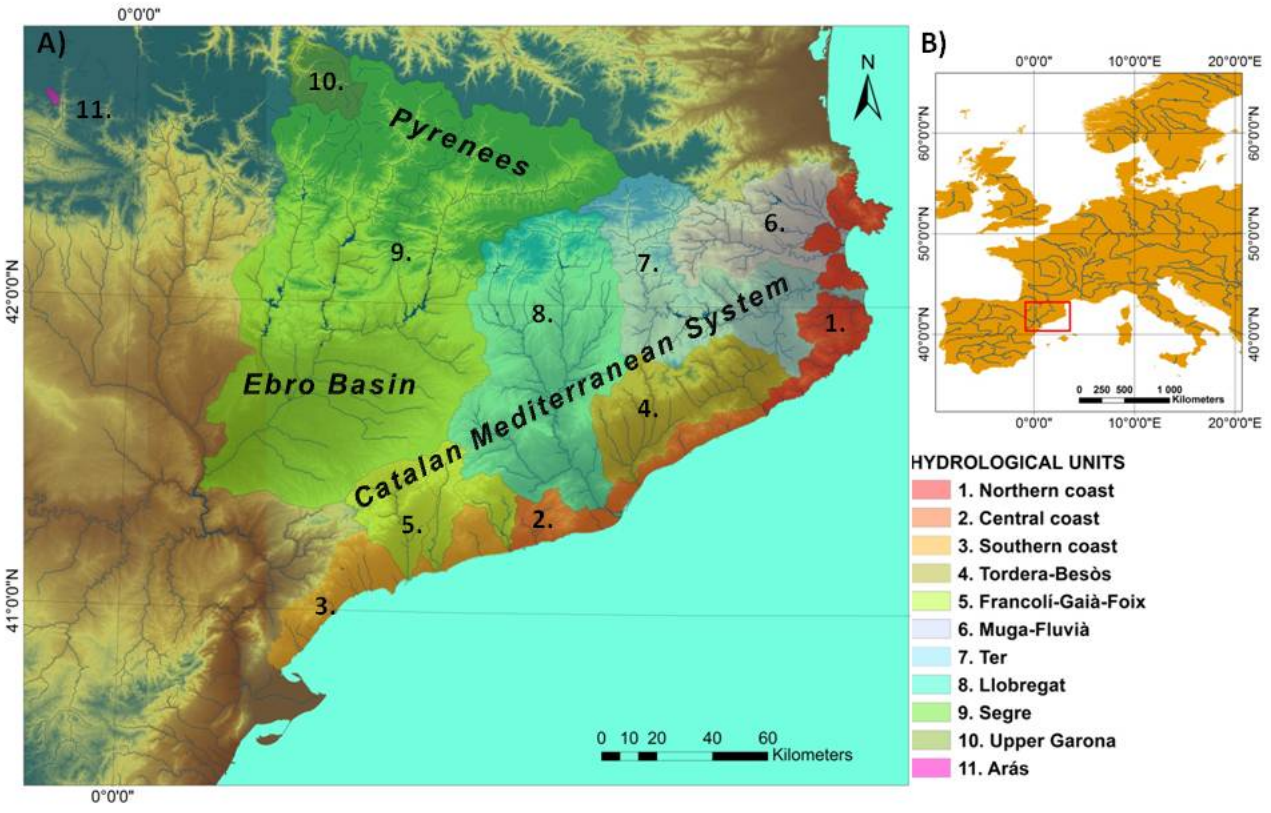

Figure 1: Study area with its eleven hydrological units (A), and its location within Western Europe (B). Own elaboration. 


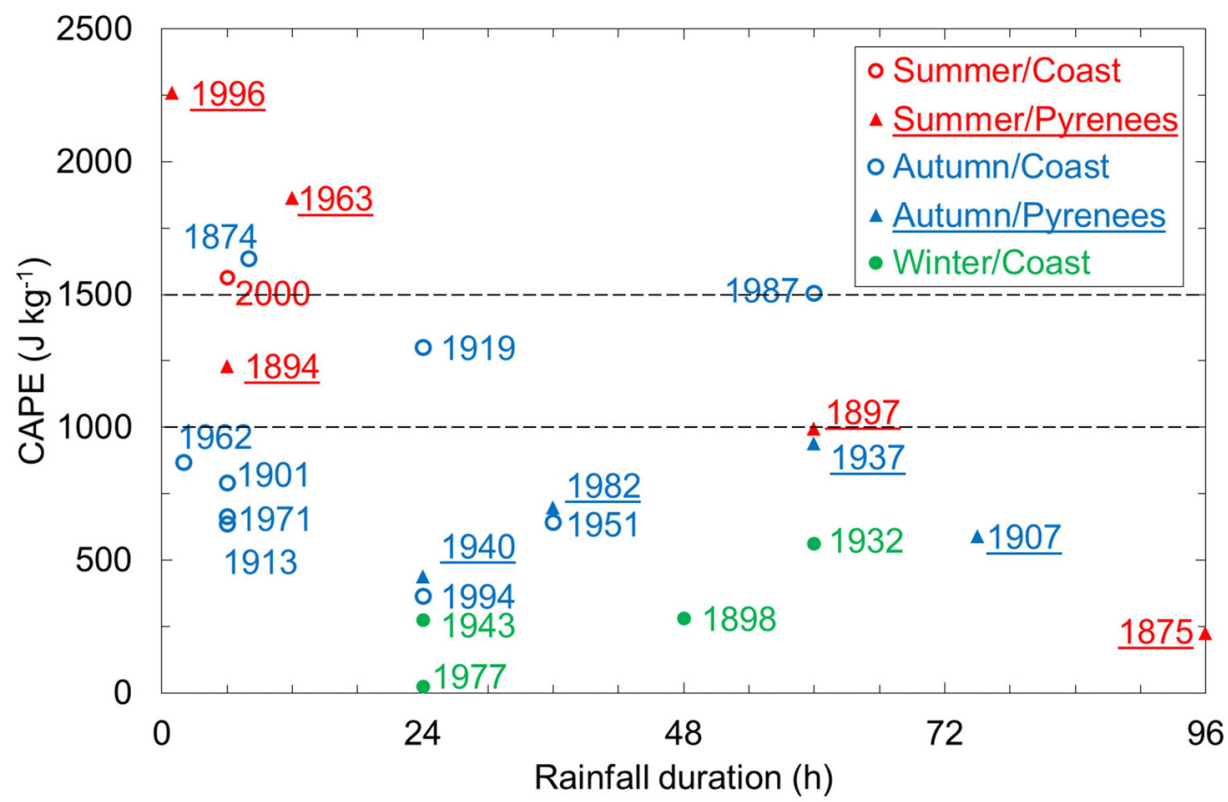

Figure 2: CAPE of each episode against rain event duration depending on season and area where it rained mainly for the 23 floods with available data (labels indicate the year of occurrence). From various sources (see Table 3 ). 

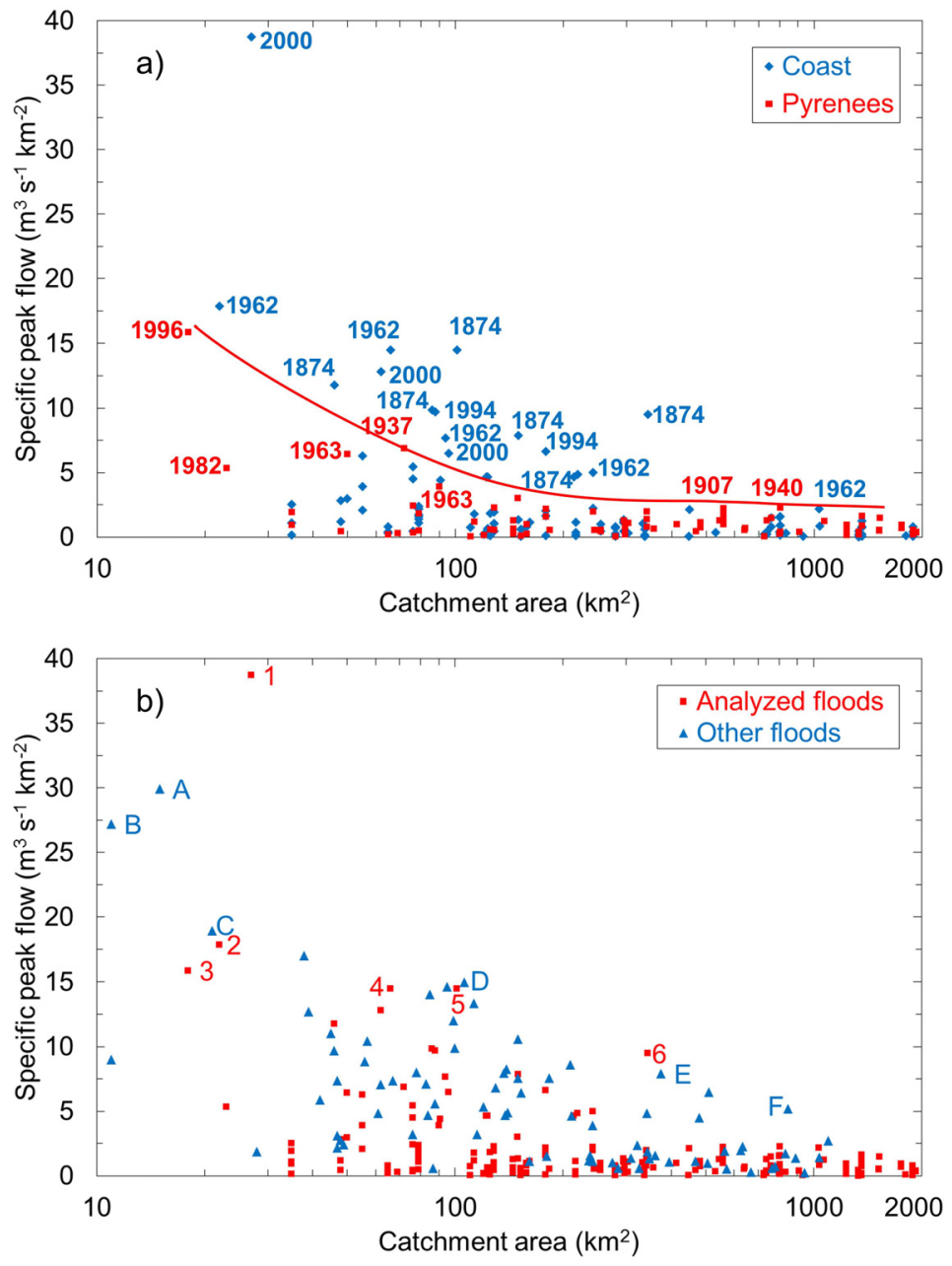

Figure 3: The 225 specific peak flow values of the 20 floods in 108 catchments smaller than 2000 $\mathrm{km}^{2}$ analyzed in this study: a) classified according to the area where it rained mainly (Coast or Pyrenees) with a line joining the maximum values in the Pyrenees, and (b) compared to the highest ever measured or modeled in other catchments in the western Mediterranean area (labelled Other floods). Key: 1: Riera de Marganell $1.5 \mathrm{~km}$ upstream the junction with the Llobregat river (10/06/2000; Pujadas (2015)), 2: Riera de Rubí in Matadepera (25/09/1962; López-Bustos (1981)), 3: Barranco de Arás in Biescas (07/08/1996; García-Ruiz et al. (2004)), 4: Riera de Rubí in Rubí (25/09/1962, López-Bustos (1981)), 5: Francolí in L'Espluga de Francolí (23/09/1874; Ruiz-Bellet et al. (2015)), 6: Francolí in Montblanc (23/09/1874; RuizBellet et al. (2015)), A: Alzon in Saint Jean du Pin (08-09/09/2002; Delrieu et al. (2005)), B: Ourne in Tornac (08-09/09/2002; Delrieu et al. (2005)), C: Amous in Générargues (0809/09/2002; Delrieu et al. (2005)), D: Solenzara in Corsica (31/10/1993 to 01/11/1993; Lang \& Coeur (2014)), E: Tech in Amélie-les-Bains (16-20/10/1940; Lang \& Coeur (2014)), F: Eyrieux at junction with Rhône (10/09/1857; Lang \& Coeur (2014)). Other sources: Nguyen et al. (2014); see Table 3. 


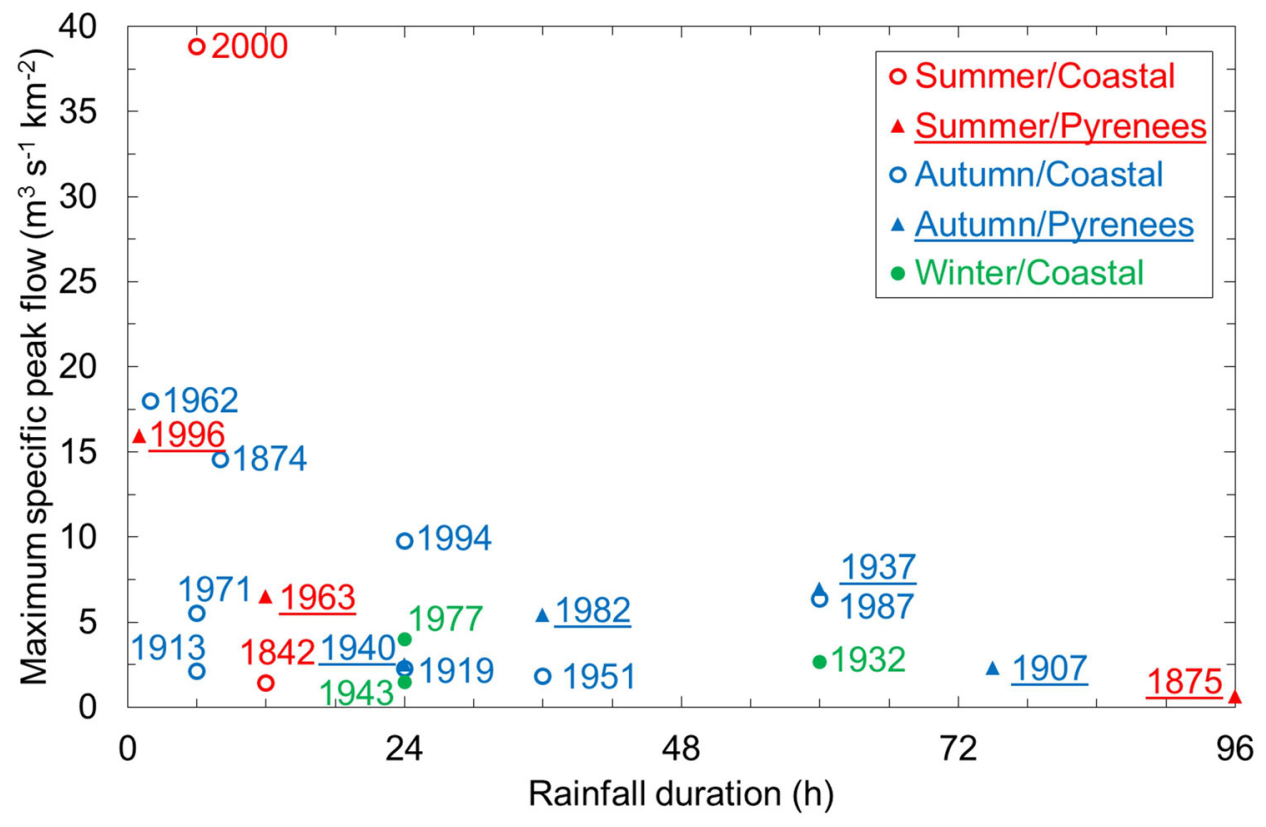

Figure 4: Maximum specific peak flow value of each flood against rain event duration depending on season and area where it rained mainly for the 20 floods with available data (labels indicate the year of occurrence). 


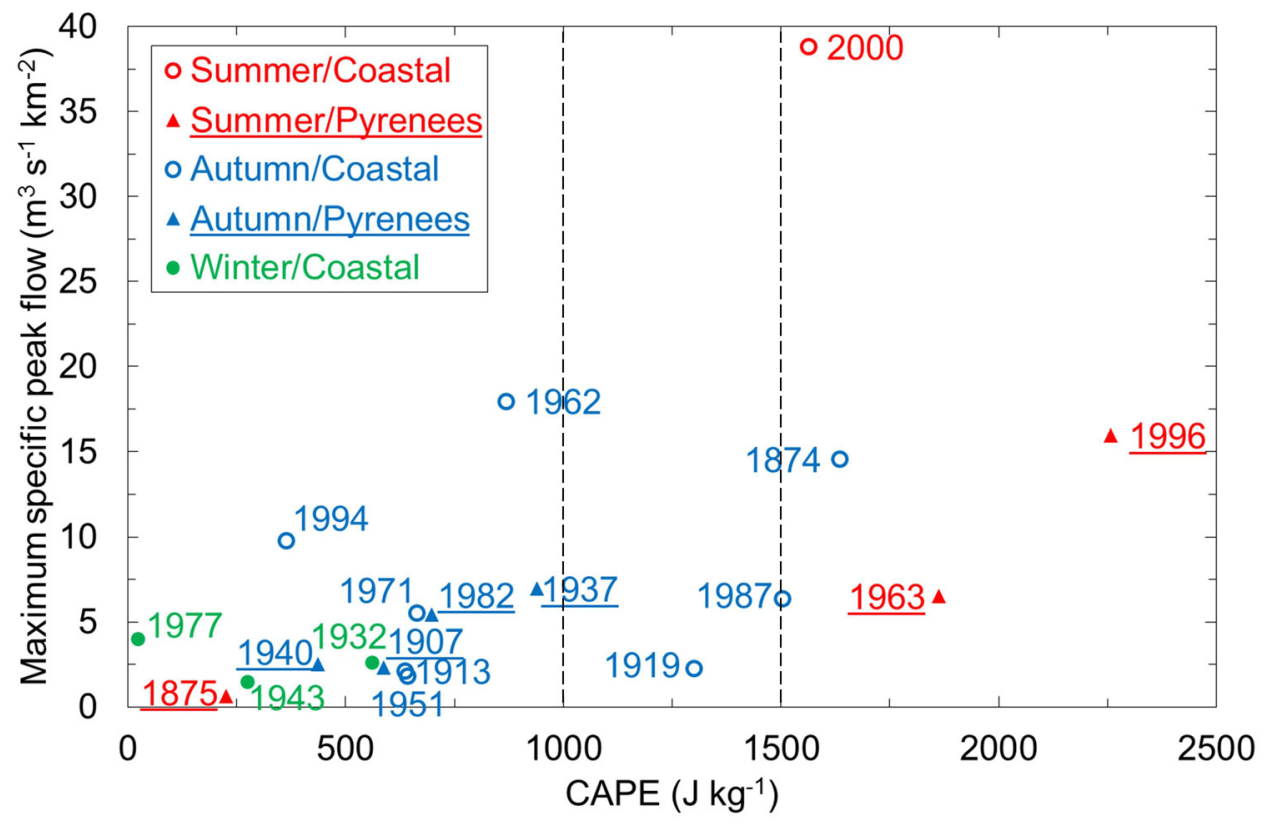

Figure 5: Maximum specific peak flow value of each flood against maximum CAPE depending on season and area where it rained mainly for the 19 floods with available data (labels indicate the year of occurrence). 

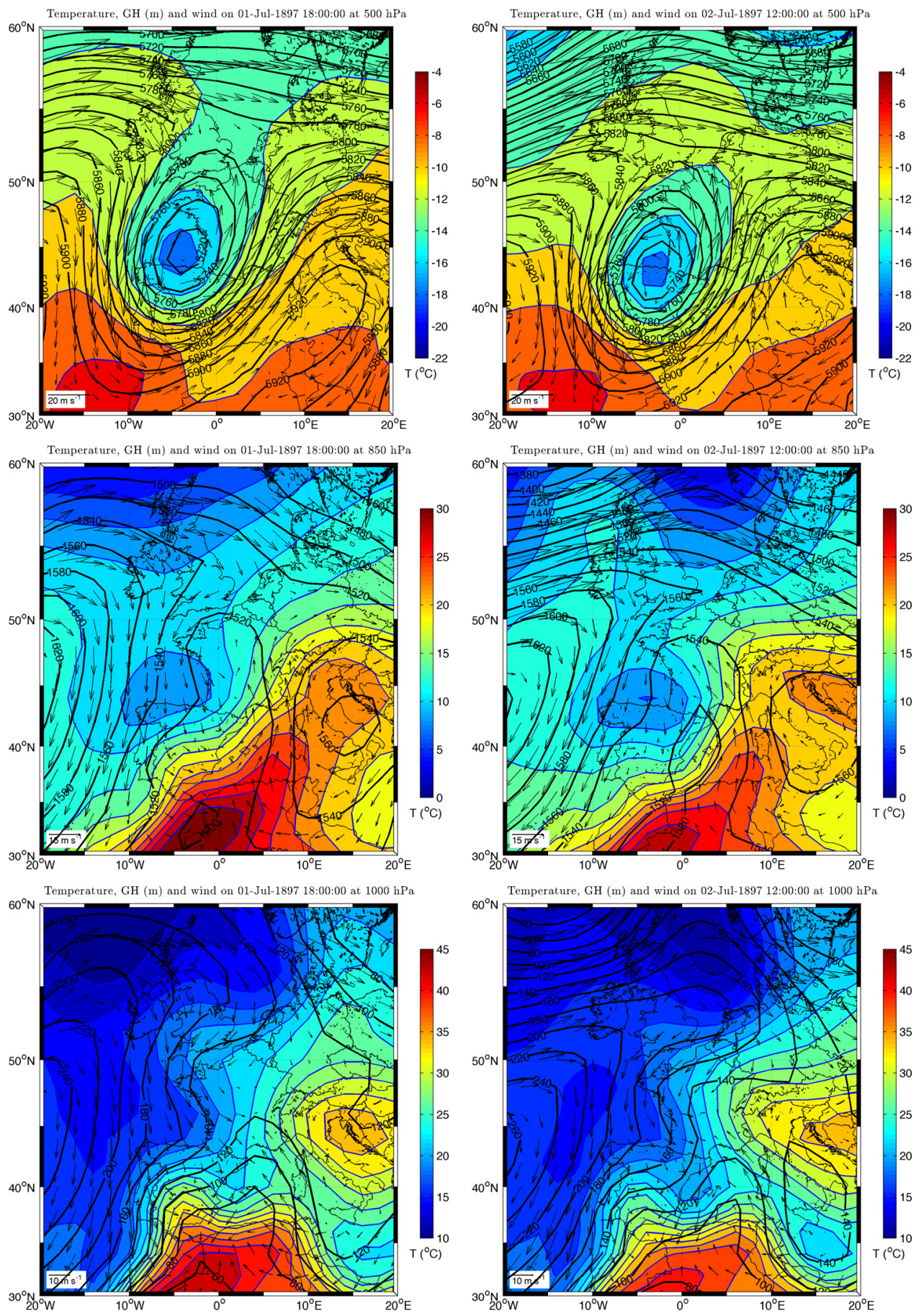

Figure 6: Temperature (color contours), geopotential height (black contours) and wind field (arrows) on (left) 1 July at 18 UTC and (right) 2 July 1897 at 12 UTC at 500, 850 and 1000 hPa. Source: NOAA CIRES Twentieth Cent7fA Global Reanalysis V2. 

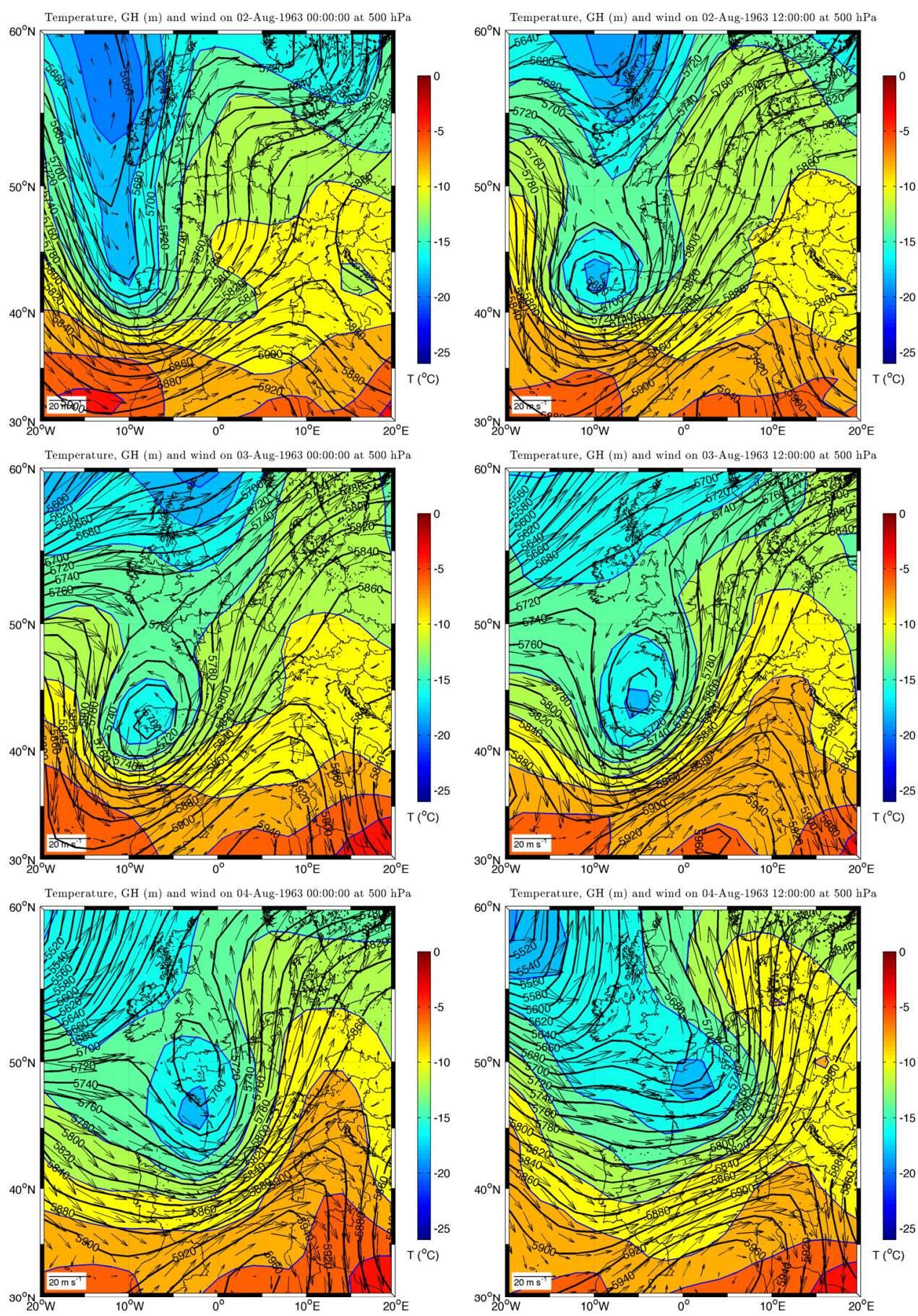

Figure 7: Temperature (color contours), geopotential height (black contours) and wind field (arrows) at $500 \mathrm{hPa}$ every 6 hours from 2 August 1963 at 00 UTC until 4 August 1963 at 12 UTC. Source: NOAA CIRES Twentieth Centły্y Global Reanalysis V2. 

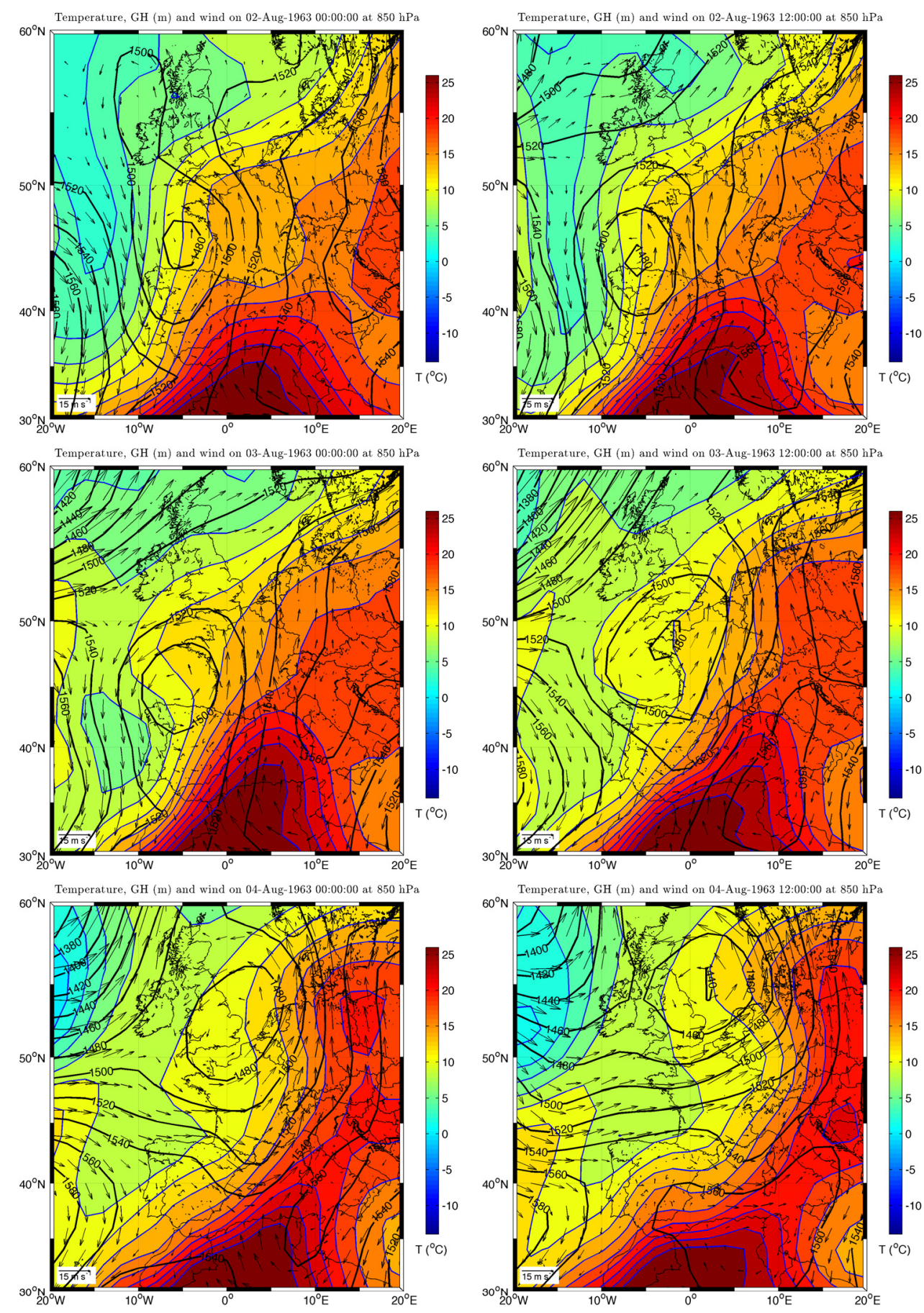

Figure 8: Same as Fig. 7 at $850 \mathrm{hPa}$. 

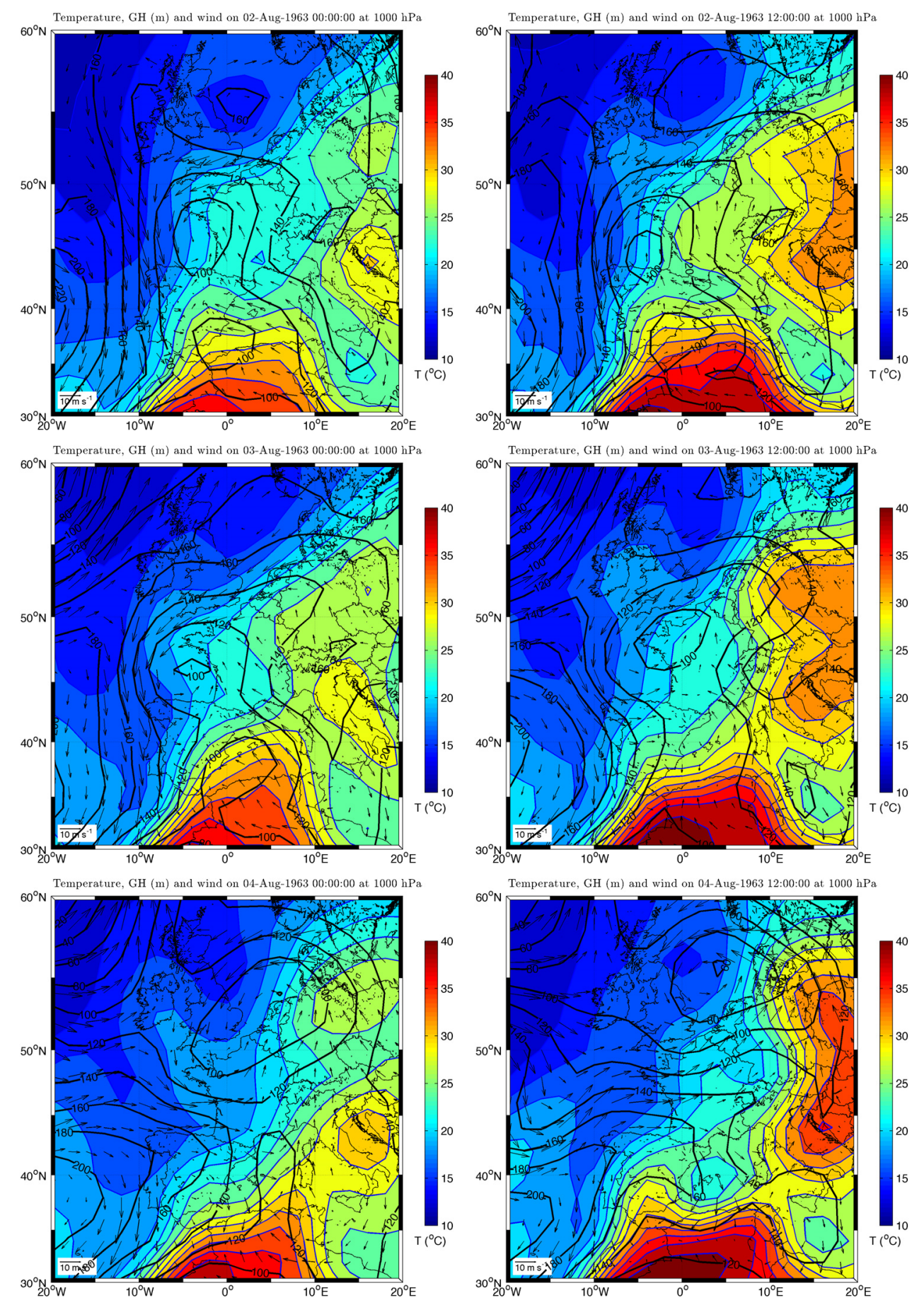

Figure 9: Same as Fig. 7 at $1000 \mathrm{hPa}$. 

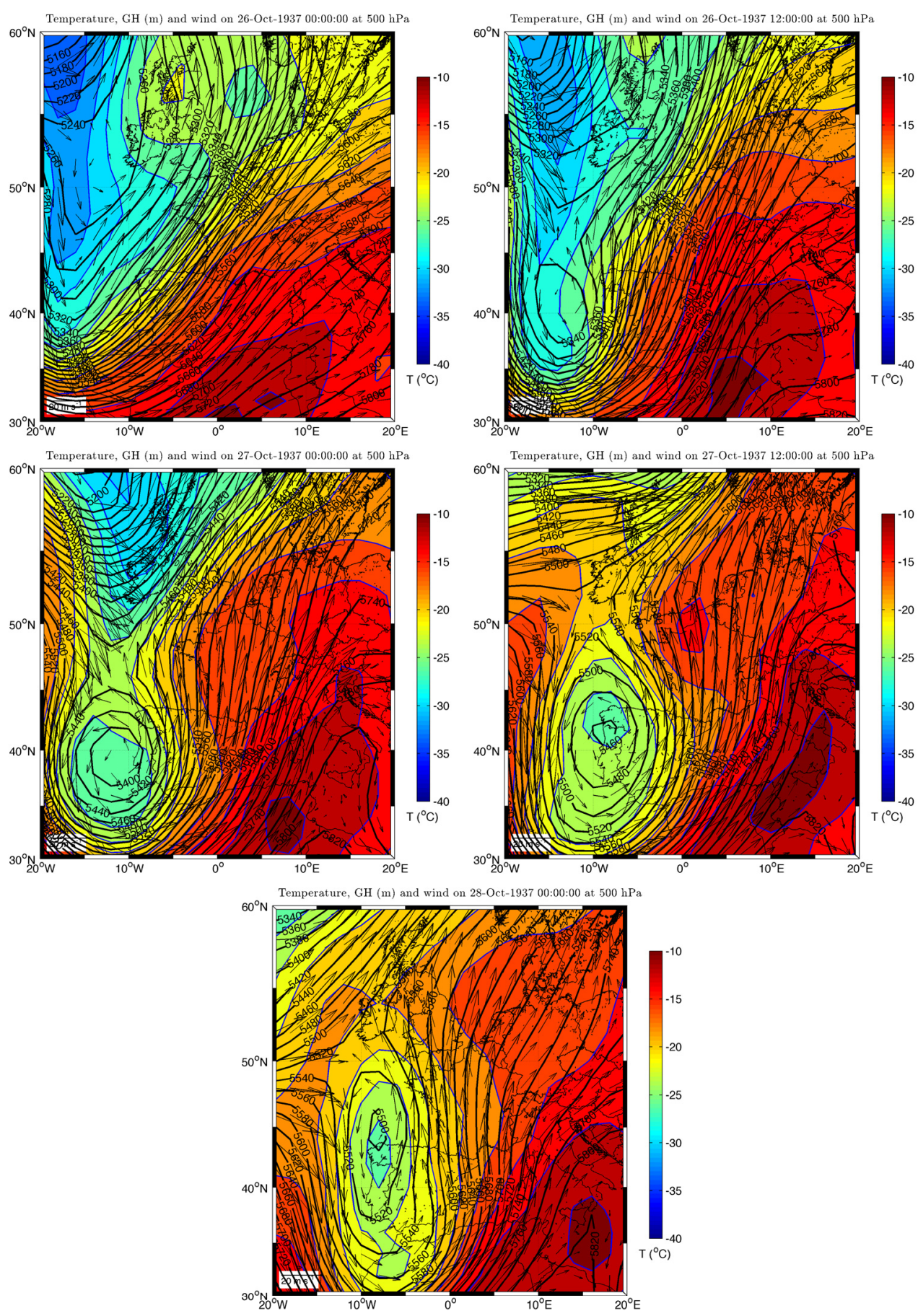

Figure 10: Temperature (color contours), geopotential height (black contours) and wind field (arrows) at $500 \mathrm{hPa}$ every 12 hours from 26 October at 00 UTC until 28 October 1937 at 00 UTC. Source: NOAA CIRES Twentieth Centyły Global Reanalysis V2. 

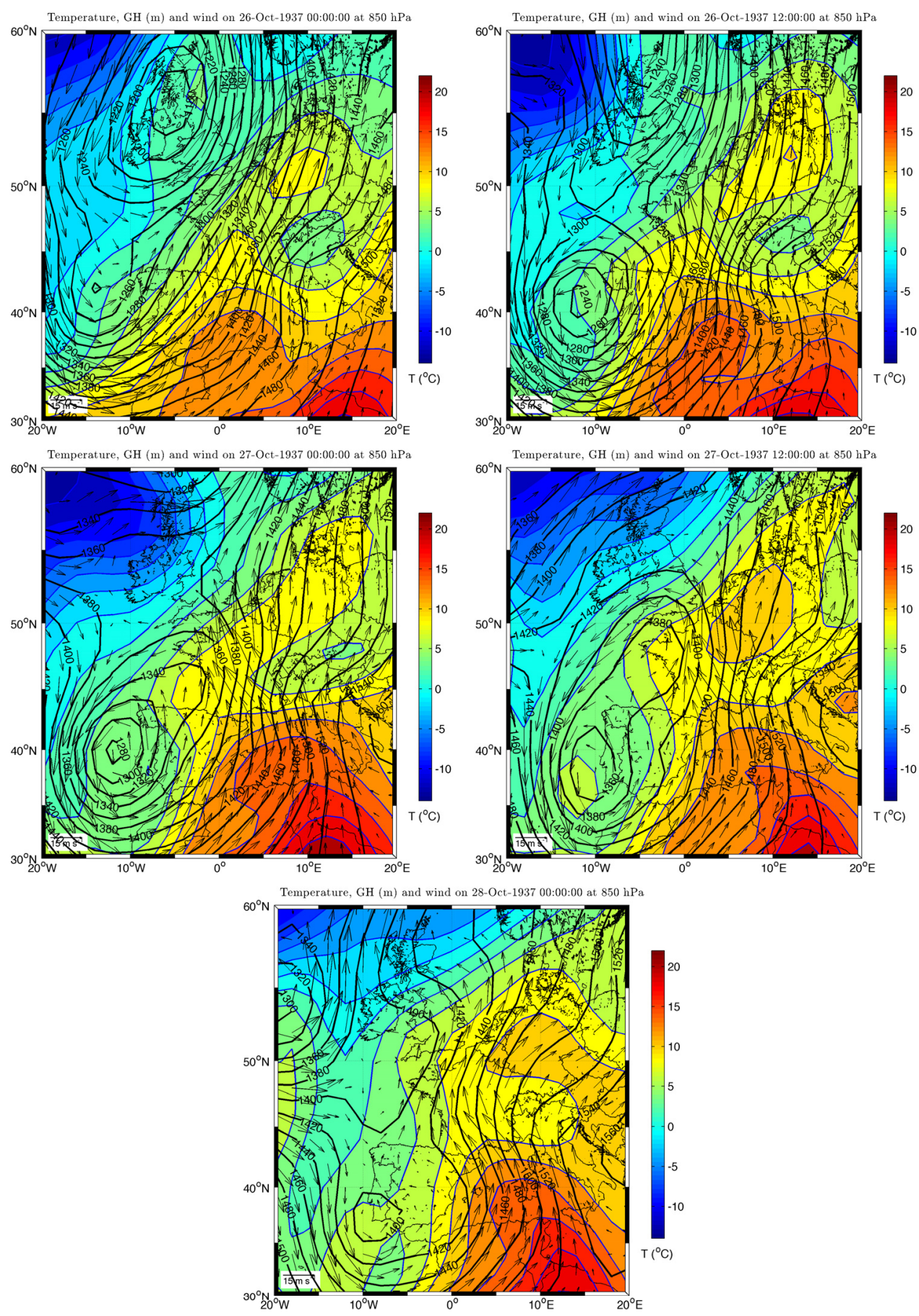

Figure 11: Same as Fig. 10 at $850 \mathrm{hPa}$. 

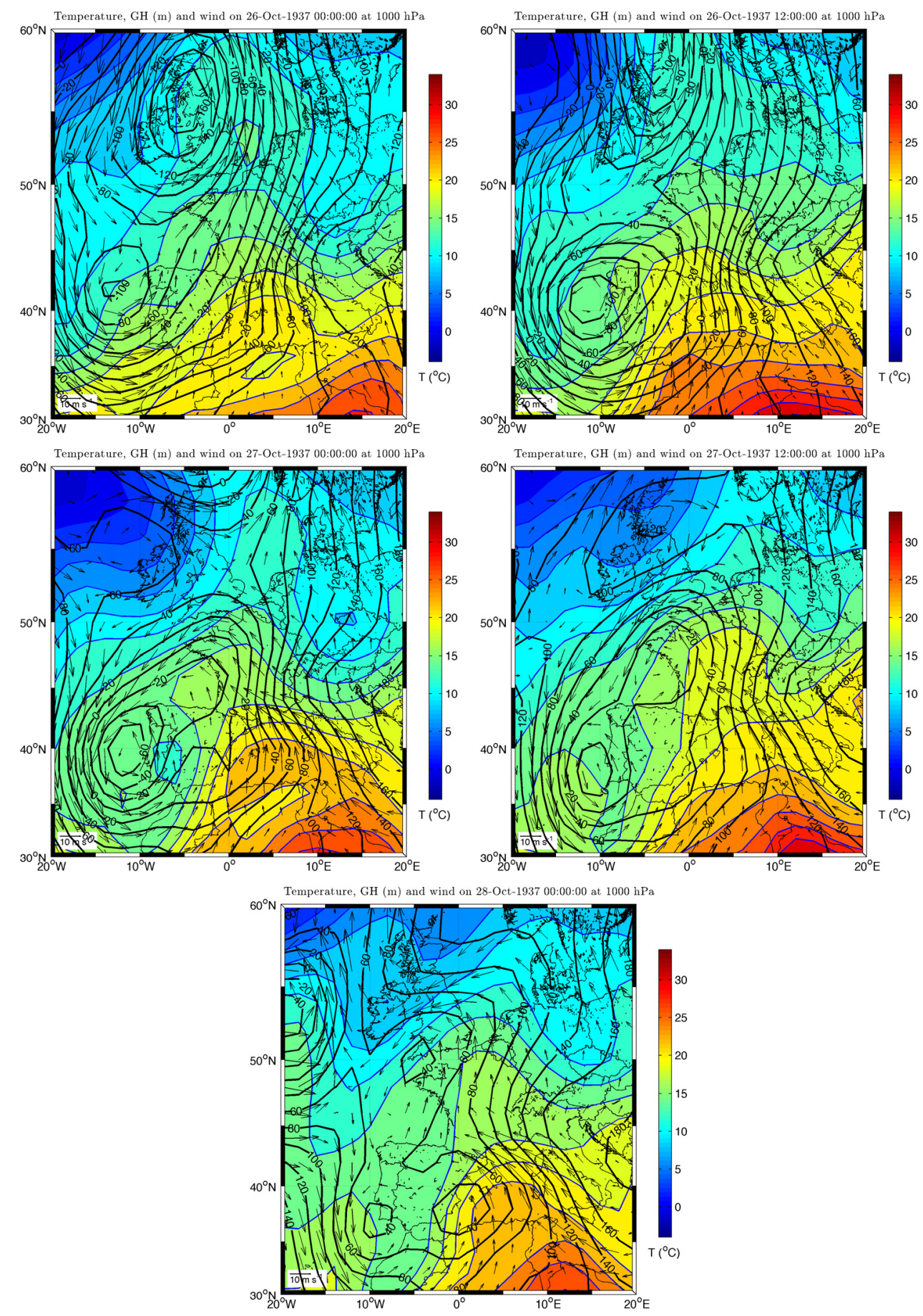

Figure 12: Same as Fig. 7 at $1000 \mathrm{hPa}$. 

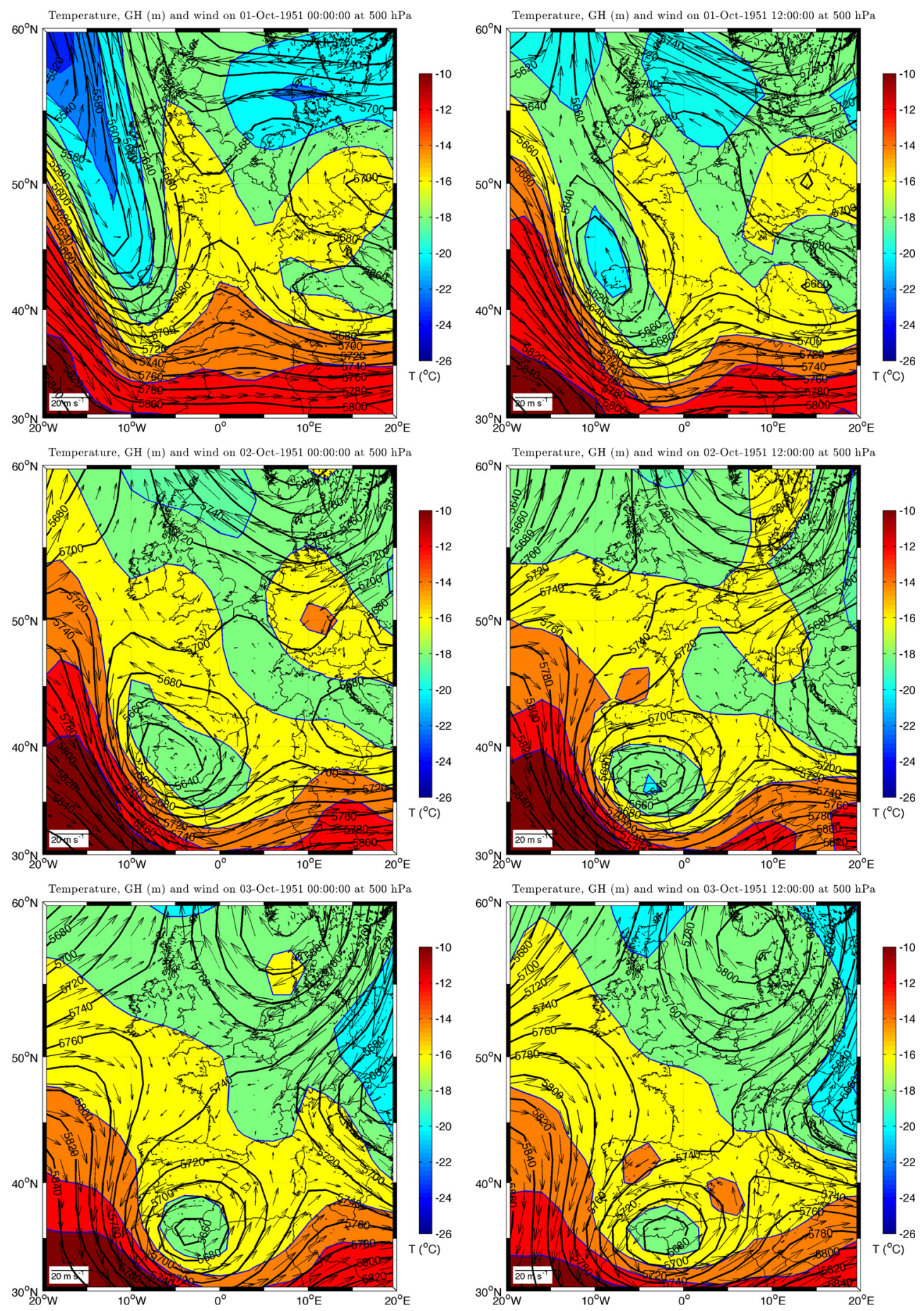

Figure 13: Temperature (color contours), geopotential height (black contours) and wind field (arrows) at $500 \mathrm{hPa}$ every 12 hours from 1 October at 00 UTC until 3 October 1951 at 12 UTC. Source: NOAA CIRES Twentieth Centiry Global Reanalysis V2. 

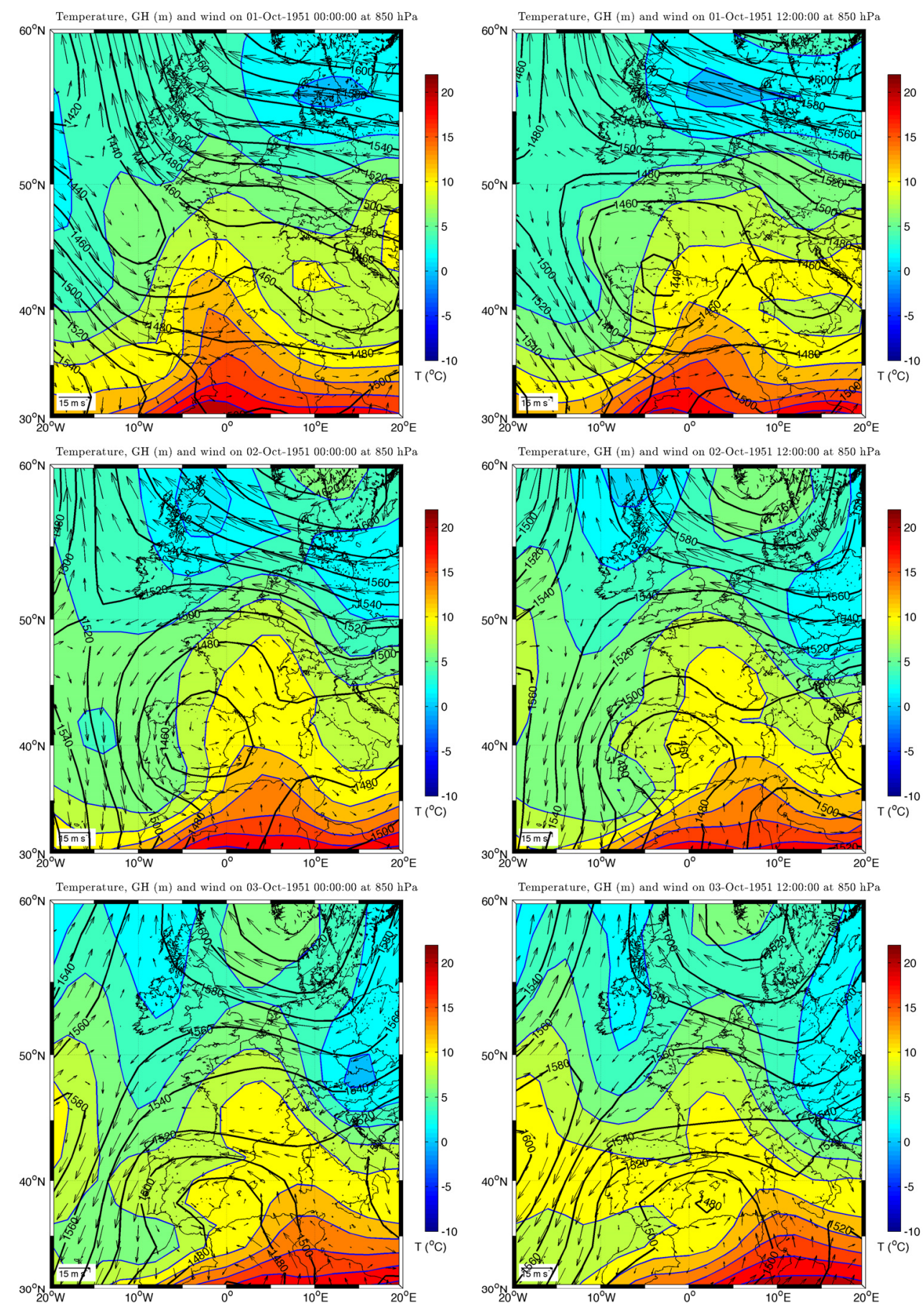

Figure 14: Same as Fig. 13 at $850 \mathrm{hPa}$. 

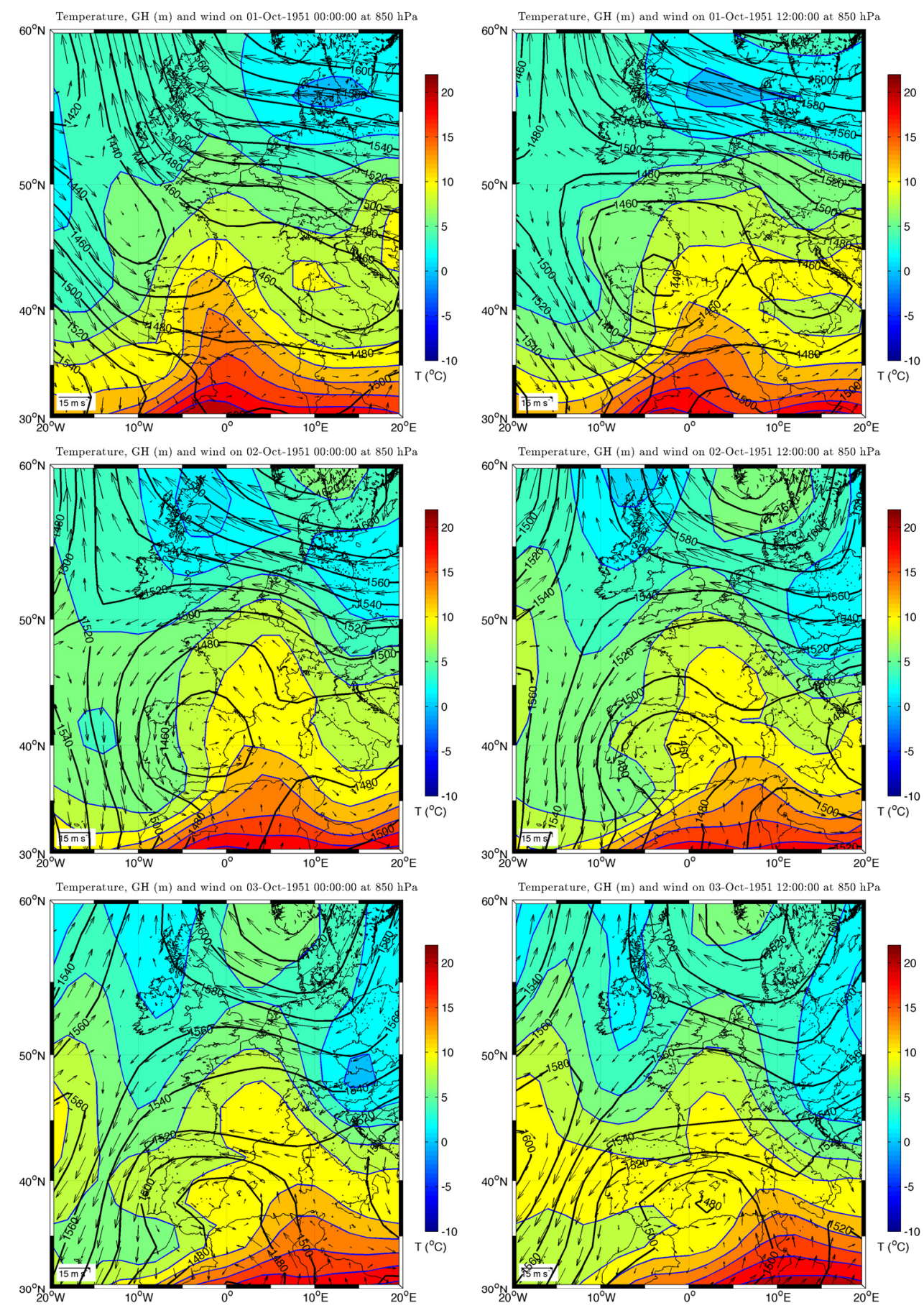

Figure 15: Same as Fig. 13 at $1000 \mathrm{hPa}$. 

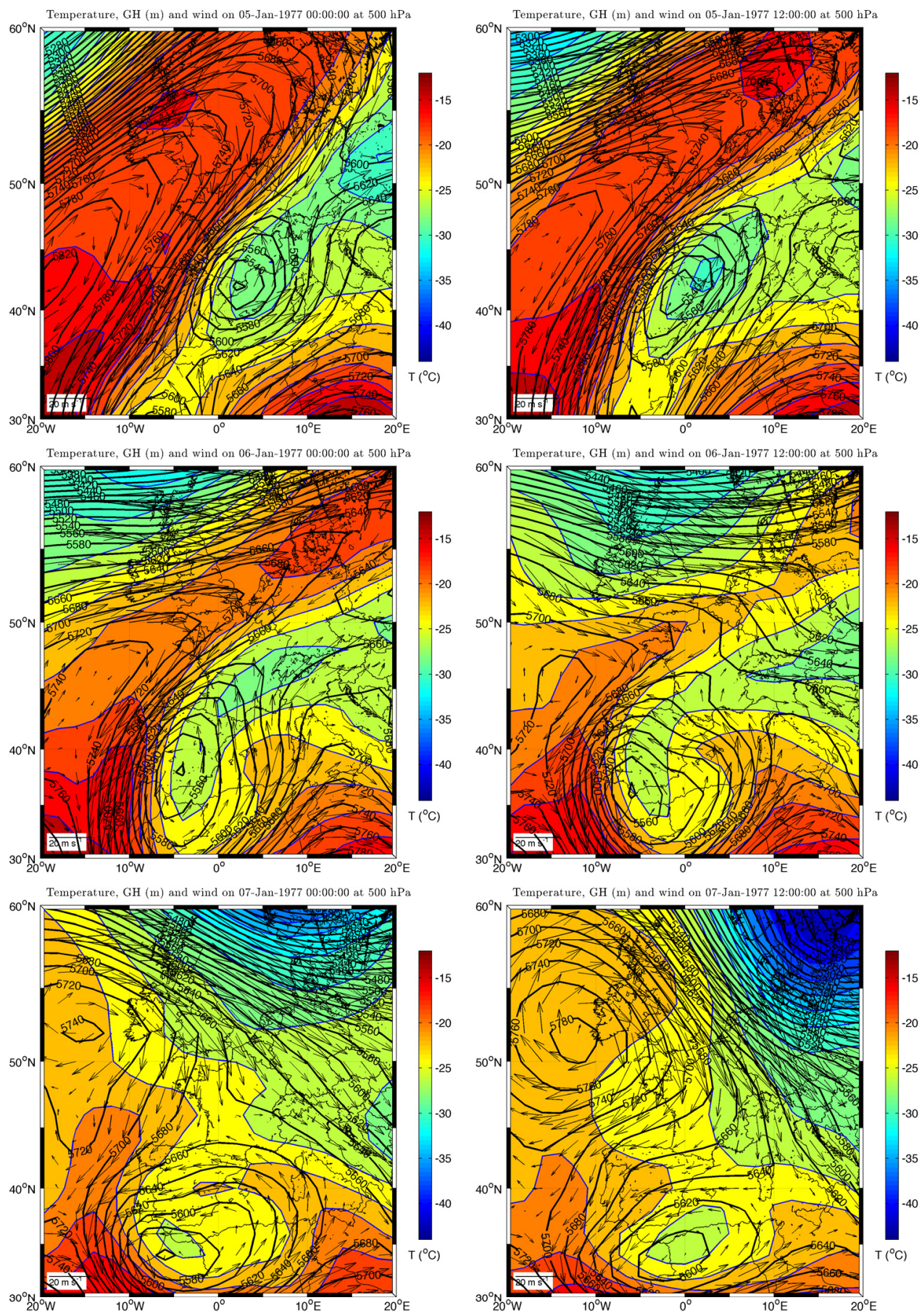

Figure 16: Temperature (color contours), geopotential height (black contours) and wind field (arrows) at $500 \mathrm{hPa}$ every 12 hours from 5 January 1977 at 00 UTC until 7 January 1977 at 12 UTC. Source: NOAA CIRES Twentieth Century Global Reanalysis V2. 

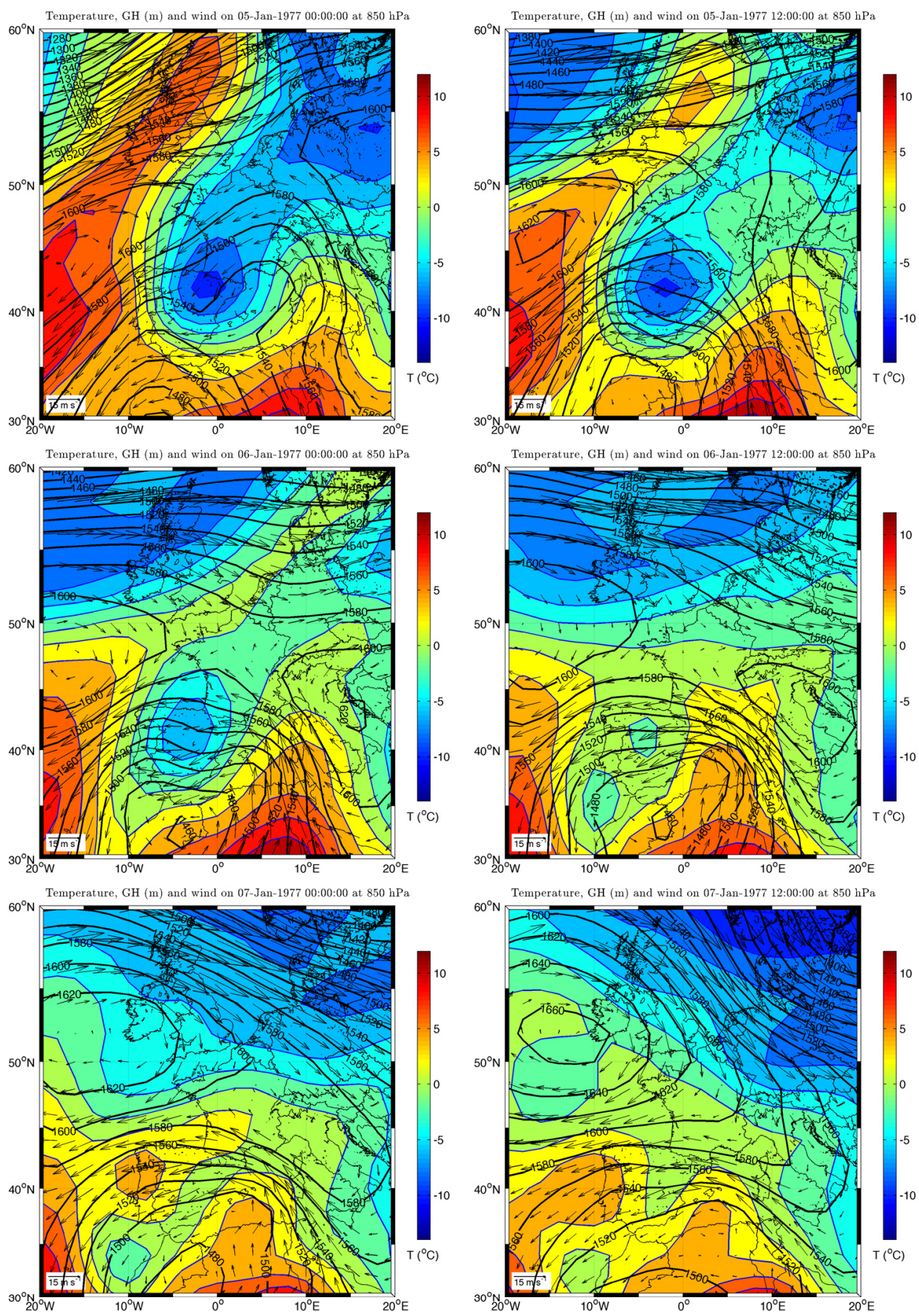

Figure 17: Same as Fig. 16 at $850 \mathrm{hPa}$. 

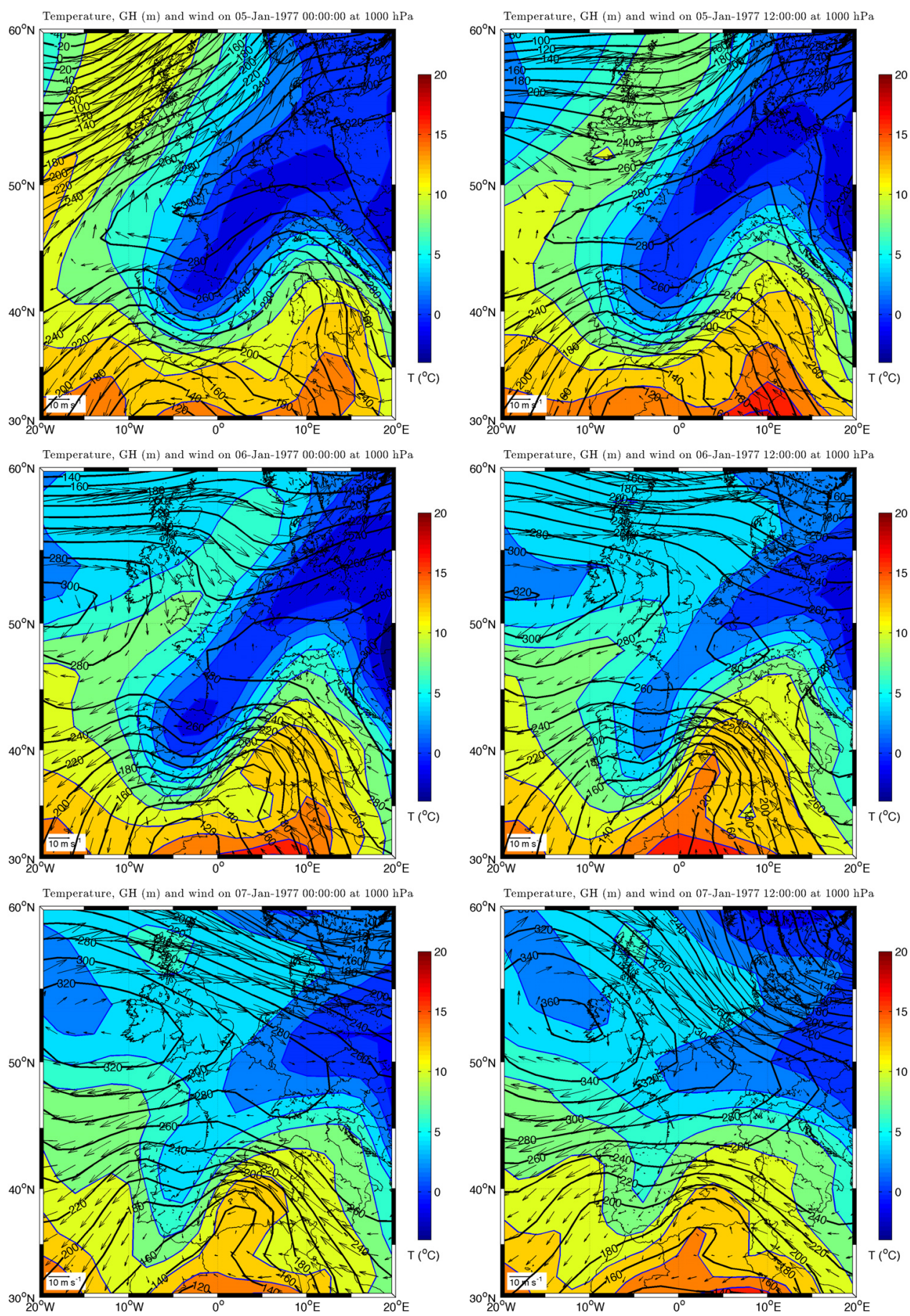

Figure 18: Same as Fig. 16 at $1000 \mathrm{hPa}$. 

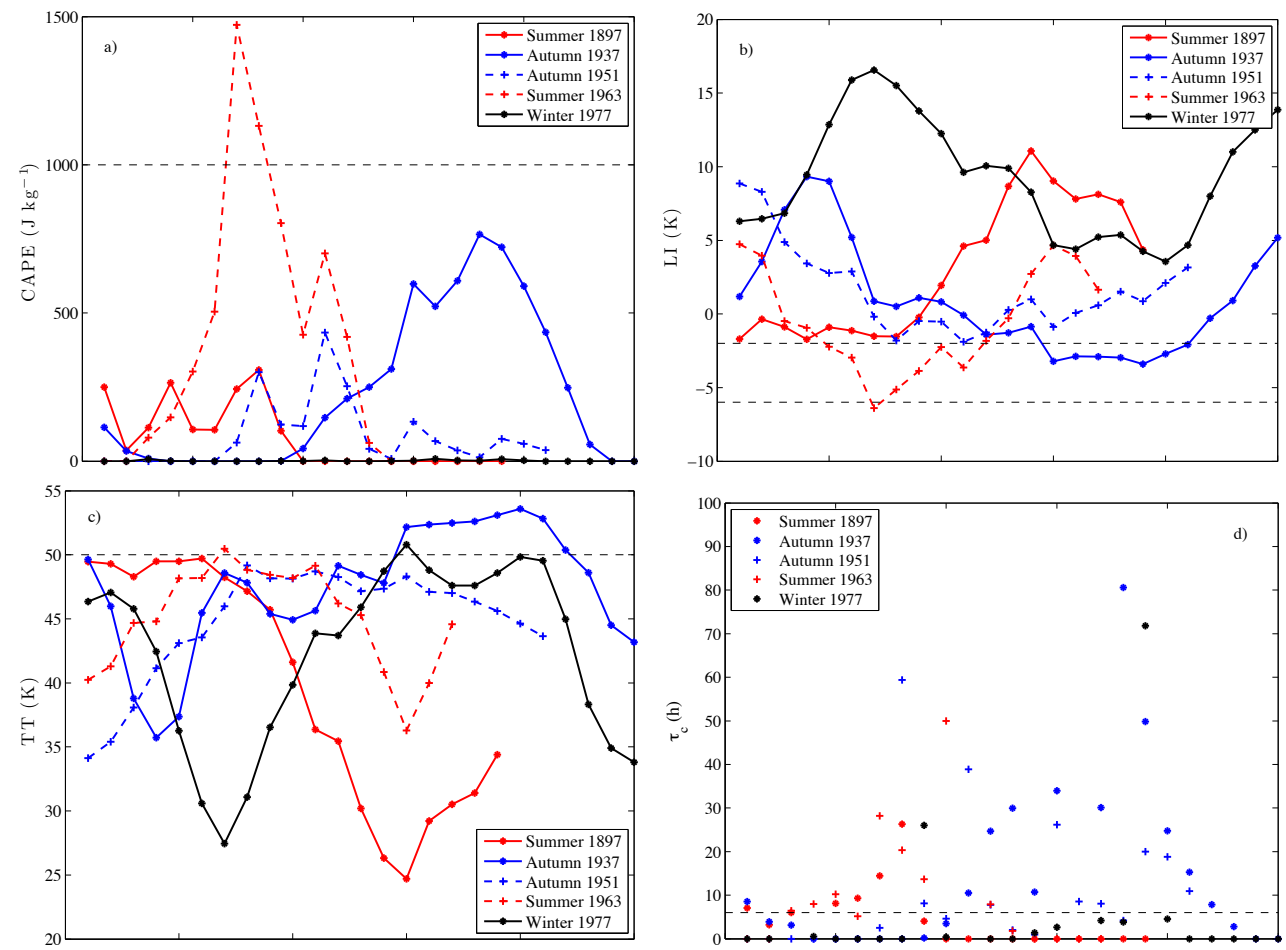

Figure 19: Temporal evolution of CAPE, LI, TT and $\tau_{c}$ at $42^{\circ} \mathrm{N}-2^{\circ} \mathrm{E}$ for the episodes occurred on 1897, 1937, 1951, 1963, and 1977. The horizontal dashed lines mark LI $=-2$ and $-6 \mathrm{~K}$ in (b) and $\tau_{c}=6 \mathrm{~h}$ in (d). 